\title{
SUJETOS (HOMO)ERÓTICOS FRENTE A LA PORNOGRAFÍA: LUGAR Y FUNCIÓN DE LA PRODUCCIÓN PORNOGRÁFICA EN LA ELABORACIÓN DE GUIONES INTRAPSÍQUICOS E INTERPERSONALES
}

\author{
Antoine Rodriguez
}

\section{RESUMEN}

Esta investigación trata sobre una serie de entrevistas individuales semiestructuradas con varones mexicanos de la ciudad de México que tienen prácticas (homo)eróticas. Las preguntas que respondieron estaban relacionadas con su manera de abordar y consumir pornografía. El objetivo fue observar, desde el ángulo de la recepción, la eventual articulación entre imágenes pornográficas y la elaboración de guiones intrapsíquicos e interpersonales en la construcción de identidades (o subjetividades) (homo) eróticas.

\section{PALABRAS CLAVE}

Pornografía, México, Guión, Sujeto, Identidad, Homosexualidad

\section{ABSTRACT}

This paper is based on a series of semi-structured individual interviews with Mexican men in Mexico City who have (homo)erotic practices. The questions they answered were related to their approach and consume pornography. The overall objective is to observe, from the pole of the reception, the possible link between pornographic images and the development of intrapsychic and interpersonal scripts in the construction of (homo)erotic identities (or subjectivities).

\section{KEY WORDS}

Pornography, Mexico, Script, Subject, Identity, Homosexuality 


\section{CONSIDERACIONES PREVIAS}

El presente trabajo se basa en una serie de entrevistas individuales semiestructuradas realizadas durante una estancia de investigación en El Colegio de México (entre agosto y diciembre de 2013), con varones de la ciudad de México que tienen prácticas (homo)eróticas. Las preguntas que respondieron estaban relacionadas con su manera de abordar y consumir pornografía (imágenes, fotografías, historietas o relatos sicalípticos, películas y videos pornográficos). El objetivo general era observar, desde una perspectiva de consumo y recepción, la eventual articulación entre imágenes pornográficas (o pornificadas, como se verá más adelante) y la elaboración de guiones intrapsíquicos e interpersonales, ${ }^{1}$ en la construcción de identidades (o subjetividades) (homo)eróticas.

Para llevar a cabo esta investigación, entrevisté a 15 sujetos con edades comprendidas entre los 24 y 76 años, todos residentes en la ciudad de México en el momento de la entrevista, aunque con orígenes diferentes. La elección de una muestra que abarca un amplio segmento de edades tuvo el objeto de poner en perspectiva diacrónica varios contextos de formación de identidades y averiguar las diferencias, si existían, respecto a la función y el consumo de pornografía. Todos los informantes — salvo uno, de 25 años, que dejó la secundaria para trabajar como estilista - tienen estudios universitarios y pertenecen a una clase media con cierto poder adquisitivo. ${ }^{2}$

1 Las nociones de "guión intrapsíquico" y de "guión interpersonal" se definirán más adelante.

2 Aunque los contornos definitorios de la "clase media" son vagos, consideramos como criterio el nivel escolar (preparatoria terminada y el haber cursado por lo menos dos años en instituciones de enseñanza superior). Respecto al nivel económico, y conscientes de lo aproximativa que pueda
Por consiguiente, las observaciones sólo revelarán tendencias, semejanzas y diferenciaciones de sujetos de clase media urbana. Quedará pendiente un trabajo de campo más exhaustivo que abarque narrativas de sujetos de clase popular y sujetos de clase alta.

Se hizo una elección previa de manera aleatoria a partir de contactos personales en la red social de Facebook. La lista fue aumentando con algunos contactos de mis informantes. No todos son amigos personales, pero sí personas con quienes interactúo vía el "muro" virtual de Facebook, a través de "comentarios" que van desde el chisme y el chiste, hasta reflexiones más elaboradas, aunque generales, sobre producciones culturales (cine, literatura, teatro, teoría y prácticas queer, etcétera) La tabla 1 , en anexos, detalla la composición del grupo de informantes (edad, profesión, relación amorosa, residencia de origen y actual, autodefinición).

La idea de esta investigación tiene su origen en lecturas teóricas provenientes de los recientes Estudios Porno ${ }^{3}$ (o Porn Studies), que abordan la producción pornográfica (esencialmente audiovisual, pero también literaria y fotográfica) en tanto régimen discursivo acerca de unas prácticas sexuales codificadas y escenificadas (sexo oral, penetración anal, masturbación, etc.), cuyo objetivo principal es provocar una excitación sexual (masturbación o excitación para el acto sexual) en los consumidores. La mayoría de los trabajos consultados, por no decir la totalidad, si bien abordan la pornografía desde

resultar la afirmación, consideramos que, a partir de tres salarios mínimos (unos 6,000 pesos mexicanos mensuales, como base), el sujeto posee cierto poder adquisitivo.

3 Entre los trabajos más destacados se pueden citar: Gubern, 1989; Williams, 1989, 2004; Yehya, 2004; Giménez Gatto, 2007, 2011; Preciado, 2008, 2010; Cervulle y Rees-Roberts, 2010. 
varias perspectivas, esto es, hacen un repaso histórico del género, observaciones sobre las modalidades de la producción pornográfica como texto cultural, reseñas de entrevistas a productores y actores porno, análisis fílmico, examen sociológico y filosófico, pocas veces consideran el ángulo de la recepción, ángulo en el que se centra el presente trabajo. ¿Cómo reciben la pornografía quienes la consumen? ¿Qué papel, en su caso, cumple la pornografía en la construcción de subjetividades? ¿Cuál es su función en la construcción de una identidad (homo)erótica?

El marco teórico para abordar la pornografía en la configuración de identidades (homo)eróticas se basa en los aportes teóricos de los estudios porno, lo que me permitió una puesta en perspectiva de dichos aportes con las narrativas y reflexiones personales de los consumidores (homo)eróticos de pornografía. A modo de síntesis, destaco los siguientes elementos:

a) La pornografía constituye no un espacio cultural marginal sino un género popular por excelencia (Cervulle y Rees-Roberts, 2010: 55).

b) Linda Williams (1989), basándose en la teoría foucaultiana sobre la sexualidad, como señalan Cervulle y Rees-Roberts (2010), concibe la pornografía como régimen discursivo (al igual que la medicina o el derecho) que contribuye a producir la verdad de los cuerpos sexuados, ciertos saberes y cierta voluntad de saber sobre la sexualidad. La pornografía sería una de las "máquinas de lo visible" (machines of the visible) que produce a los sujetos a los que se supone representa. c) Según Fabián Giménez Gatto, cuya elaboración teórica sobre la postpornografía se nutre parcialmente de las aportaciones teóricas de Jean Baudrillard, la pornografía es "ficcionalización del placer sexual, teatralización obsesivamente codificada, con inicio, nudo y desenlace de los flujos del deseo". "La mirada pornográfica", nos dice, "es obscena por su inmediatez, por su literalidad, obsesión por representar la realidad del sexo, reflejar de manera transparente su 'verdad' bajo la égida de lo explícito como sinónimo de lo verdadero" (2011: 98).

d) Para Naief Yehya, la pornografía "es el teatro de la carnalidad en el que se ponen a prueba los límites de lo permisible. La pornografía podría ser definida como la expresión del sexo por el sexo mismo sin pretextos ni justificaciones, como aquella forma de expresión en la que el sexo tiene tal predominancia que podemos olvidar el tema, el contexto, las subtramas y todo detalle de la historia" (2004: 16). Por otra parte, para Yehya, "la pornografía no se define por lo que muestra sino por las reacciones que provoca en el público" (2004: 251).

e) Según Roman Gubern, el cine porno privilegia el mostrar sobre el narrar (1989: 13).

f) Beatriz Preciado, tomando como punto de partida los Porn Studies, considera que la pornografía es "un dispositivo virtual (literario, audiovisual, cibernético) masturbatorio" (2008: 179). Es una puesta en espectáculo de la sexualidad, una extensión de los espectáculos populares del 
circo, un dispositivo de "publicación de lo privado" (2008: 180). Añade que "la pornografía dice la verdad de la sexualidad, no porque sea el grado cero de la representación, sino porque revela que la sexualidad es siempre y en todo caso performance, representación, puesta en escena" (2008: 181).

g) En esta línea analítica se sitúa también Giménez Gatto cuando afirma que "en el porno, el sexo no miente, es enfático y directo, confiesa todos sus secretos a través de erectilidades, penetraciones, fluidos [...] Verdad eréctil y eyaculatoria, donde el éxtasis del sexo coincide con el éxtasis de lo real, al menos eso es lo que nos intentan hacer creer" (2011: 69).

Estas observaciones sirvieron de fuente de inspiración para considerar, como posible punto de partida, que la pornografía es un régimen discursivo, es decir, un conjunto de representaciones y normas escenificadas acerca de unas prácticas sexuales que dan la impresión de revelar la verdad sobre lo que podríamos llamar el "buen sexo" y la "buena manera" de practicarlo. Intentaremos ver si la pornografía es percibida como una utopía sexual, un "no-lugar" o "lugar irreal" idealizado, en el que se proyectan los consumidores en busca de placer corporal, esencialmente masturbatorio. Por otra parte, trataremos de dilucidar si la pornografía, en tanto dispositivo discursivo masivamente difundido, y por consiguiente masivamente recibidoconsumido, tiene, como los medios de comunicación en general, capacidad para fabricar subjetividades y determinar contornos identitarios. ${ }^{4}$ Para interpretar

4 Esta idea está inspirada en las observaciones de Simon y dar cuenta de dichas narrativas y reflexiones, es de particular importancia hablar de las nociones de identidad, sujeto y script (guión).

\section{IDENTIDAD, SUJETO (HOMO)ERÓTICO Y SCRIPT}

La noción de identidad está estrechamente vinculada a la de sujeto, ya que no hay identidad sin sujeto que la organice, la interiorice y la reproduzca performativamente, es decir, de manera iterativa. Según Gilberto Giménez, la identidad consiste en "la apropiación de ciertos repertorios culturales que se encuentran en nuestro entorno social, en nuestro grupo o nuestra sociedad" (2013: 1). El autor concibe la identidad como una manera de interiorizar la cultura "en forma específica, distintiva y contrastiva por los actores sociales en relación con otros actores" (2013: 1), por eso la identidad consta de dos tipos de atributos: "los atributos de pertenencia social que implica la identificación del individuo con diferentes categorías, grupos y colectivos sociales" y "los atributos particularizantes que determinan la unicidad idiosincrásica del sujeto en cuestión" (2013: 10). La adquisición de una identidad psico-socio-cultural se hace mediante un proceso de socialización ${ }^{5}$ durante el cual el individuo Watney (Policing Desire: Pornography, AIDS, and the Media, Minneápolis, University of Minnesota Press 1987), citadas por Leo Bersani en el ensayo "¿Es el recto una tumba?" (1995): "El gran poder de los medios de comunicación estriba, como escribe Watney (1987: 125), en "su capacidad para fabricar la subjetividad", y, consecuentemente, en su capacidad para determinar los contornos de una identidad" (Bersani, 1995: 88).

5 De acuerdo con Edith Yesenia Peña Sánchez, la socialización es "el proceso por el cual los individuos que forman parte de una sociedad, aprenden los códigos, normas y valores culturales con los que interaccionan unos con otros, son las pautas que dan dirección a su comportamiento en colectividad" (Peña Sánchez y Hernández Albarrán, 2011: 38). 
interioriza los patrones o normas de comportamiento sociales (relativos al sexo, género y sexualización, por ejemplo) establecidos y legitimados a través de una serie de representaciones que ejercen un poder en el individuo. Dicho de otro modo, y de acuerdo con los aportes teóricos de Núñez Noriega, ${ }^{6}$ el individuo interioriza, incluso incorpora, una serie de reglas, valoraciones y conceptuaciones naturalizadas como elementos fundacionales del orden y de la interacción social. "No existe", señala Núñez Noriega refiriéndose a la sexualidad, "una existencia sexual que no haya sido construida en un contexto social y en la exposición constante a la acción de las representaciones sociales". Y añade: "La dimensión bio-psíquica-social involucrada en la vivencia del placer y del deseo erótico es producto y productora de representaciones sociales" (1999: 37). Esto conduce a considerar que los procesos de legitimación de la sexualidad "gay" obedecen también a una serie de representaciones, emitida por varios grupos "militantes", que van no sólo a entrar en tensión con las representaciones hegemónicas de la sexualidad heterosexual, sino también a producir a su vez tendencias hegemónicas dentro de la amplia y diversa comunidad gay.

Ahora bien, si consideramos que, por una parte, las normas, las reglas y las "buenas" maneras de comportarse socialmente (derivan de/son resultado de) se traducen por una serie de representaciones o de producciones discursivas dotadas de prestigio social, y se intentan imponer mediante acciones coercitivas o induciendo la idea de que están elaboradas para el bien(estar) del individuo y el orden de la sociedad,

6 Núñez Noriega se inspira en las aportaciones teóricas de Michel Foucault y de Pierre Bourdieu. y que, por otra parte, estas representaciones, como lo mostró Michel Foucault, ejercen cierto poder, provocando determinada manera de percibir y de construir el cuerpo, la sexualidad y la forma de relacionarse con los demás, cabría preguntarse, ¿qué sucede cuando el individuo, frente a las reglas y a las normas sociales hegemónicas que limitan, inhiben o denigran sus acciones y su comportamiento sexual, las interioriza sólo parcialmente? ¿Qué sucede, por ejemplo, cuando el individuo, en vez de convertirse en el sujeto hombre-masculino-heterosexual, aún en vigor en la hegemonía social, se va percibiendo o definiendo como sujeto-masculino-homosexual o sujeto-femenino-homosexual? Para responder a tales cuestionamientos es necesario, primero, hacer un breve repaso de las nociones de sujeto y de resistencia; y segundo, analizar la noción de habitus, tal y como la concibe Núñez Noriega, a partir de los trabajos teóricos de Pierre Bourdieu.

El sujeto es, siguiendo la definición de Alain Touraine, "la construcción del individuo como actor, por asociación de su libertad afirmada y de su experiencia vivida asumida y reinterpretada" (1994: 23). El sujeto es el que organiza su identidad de manera autónoma, lo que no significa que lo haga de manera independiente, ya que está él mismo sociológicamente definido (Dubet, 1989: 540). Ahora bien, por "sociológicamente definido" debemos entender el estar atravesado por una serie de representaciones políticas y lingüísticas que actúan desde el momento en que el ser humano entra en el lenguaje, es decir, según la terminología lacaniana,

7 La traducción al español es mía: "la construction de l'individu comme acteur, par l'association de sa liberté affirmée et de son expérience vécue assumée et réinterprétée" (Touraine 1994: 23). 
cuando entra en el orden simbólico. "Ser sujeto", dice Judith Butler, "significa entre otras cosas, haber nacido en un mundo en el que las normas actúan desde el principio"8 (2005: 118).

Aunque sujeto (en el sentido de sometido - como reza la etimología latina de la palabra sub-jectum-) a una serie de normas o identidades socialmente codificadas, el sujeto tiene capacidad de pensar, de actuar y de producir, más que de reproducir una subjetividad. El sujeto, al afirmarse desde la toma de palabra en primera persona, al decir "yo", se convierte en una fuerza que limita el control de lo social. Más aún, el sujeto tiene la capacidad de cuestionar, aunque sólo sea de manera limitada, las normas sociales que lo oprimen. Según Wieviorka, el sujeto presenta dos rasgos: uno defensivo que resiste a las lógicas de los sistemas o de una comunidad; otro constructivo o positivo que le atribuye cierta capacidad de ser actor, de construir su propia experiencia (2011: 32).

Los informantes de esta investigación, sea cualquiera su edad, hayan nacido antes, durante o después de los movimientos de liberación homosexual, dejan claro cómo, en tanto sujetos, fueron cuestionando las normas dominantes para construir su identidad homosexual, asumirla o, en algunos casos, deconstruirla para intentar escapar de las fábricas (homo)sociales de etiquetas.

En el caso del sujeto homosexual —que en este trabajo prefiero denominar (homo)erótico, ${ }^{9}$

8 La traducción al español es mía. La versión francesa dice "Etre sujet signifie notamment être né dans un monde au sein duquel des normes agissent dès le commencement".

9 La noción de "sujeto erótico" es empleada por el antropólogo y activista gay Xabier Lizarraga Cruchaga en su ensayo "La identidad sexo-genérica: un continuo" (1987: 386): "El yo sexual se construye de realidades que poniendo entre paréntesis el prefijo "homo" porque antes de tomar conciencia y de asumir una identidad homosexual o de disidencia sexual, el individuo está condicionado para convertirse en sujeto heterosexual一, la autodefinición y aceptación de la orientación sexual "disidente" pasa por un proceso de tres etapas, según lo expone Núñez Noriega a partir de un trabajo de campo realizado con varones que tienen sexo con otros varones en Hermosillo (1999):

1. El individuo está consciente de tener sentimientos o deseos sexuales hacia personas del mismo sexo. Esto no quiere decir que se identifique como "homosexual" o que tenga conductas eróticas con otros varones.

2. El individuo define sus deseos o sentimientos sexuales hacia personas del mismo sexo como "homosexuales" y se autodefine en los mismos términos. Esto no significa que acepte para sí dicha "homosexualidad".

3. El individuo redefine la categoría "homosexual" y se acepta como tal. Generalmente esta etapa se lleva a cabo en un proceso de socialización dentro de una red de amigos y conocidos que se identifican como "homosexuales". Esta situación le permitirá conformar una identidad homosexual (1999: 180).

Frente a $-\mathrm{y}$ contra- los regímenes

van de lo exclusivamente biológico, como el sexo, hasta aquellos parámetros socioculturales que implican actuar como sujetos eróticos y políticos, amén de reproductivos". El subrayado es mío. 
discursivos (derecho, medicina, religión) y las representaciones hegemónicas que producen una imagen estigmatizada de la homosexualidad, que la definen como orientación abyecta o contra-natura, el sujeto (homo)erótico opone una resistencia, un cuestionamiento o una resignificación valorativa de la categorización dominante, valiéndose generalmente de lo que Núñez Noriega denomina el habitus grupal homosexual (1999: 161), es decir, un conjunto de disposiciones, de experiencias, de prácticas que los sujetos homosexuales comparten debido a su situación de "disidencia". Esto no significa que todas las experiencias sean iguales; son "semejantes", no "iguales", dice Núñez Noriega. Pueden inscribirse, por una parte, en la misma dinámica de confrontación a un poder coercitivo que excluye, estigmatiza o condena social y moralmente al sujeto homosexual; y por otra, pueden ser partícipes, directa o indirectamente, de la lucha de las representaciones mediante la elaboración de una serie de resignificaciones cuyos soportes abarcan campos como el de las artes plásticas, la literatura - en el sentido amplio de la palabra-o actividades diversas como marchas, programas de radio y de televisión, talleres de intercambio sociocultural, etcétera.

Hasta aquí, me he centrado en el sujeto (homo) erótico, dejando a un lado la compleja noción de sujeto queer. En el caso del sujeto queer, y de manera sintética, se trata de la reconfiguración de otro sujeto y no de su negación. Un sujeto erótico contemporáneo cuya acción identitaria consiste en cuestionar las etiquetas sexo-genéricas hegemónicas (hombre-mujer, masculino-femenino) y los comportamientos sexo-eróticos impuestos no sólo por el sistema heterosexual sino también por cierta homonormatividad de la(s) comunidad(es) gay de los años 1970-1980. La palabra queer, según Eve Kosofsky Sedgwick, se refiere a "una matriz abierta de posibilidades, los desvíos, las imbricaciones, las disonancias, las resonancias, las insuficiencias o los excesos de sentido cuando los elementos constitutivos del género y de la sexualidad de alguien no se sujetan (o no pueden sujetarse) a significaciones monolíticas"10 (1998: 114).

Desde un punto de vista histórico, las configuraciones de la identidad homosexual/gay han pasado por varias etapas. A un periodo de estigmatización como conducta abyecta, en el que se consolida la identidad heterosexual (siglo XIX y primera mitad del XX), le sigue una etapa de resignificación positiva llamada liberación homosexual (años 1970) en la que se configura un sujeto gay hegemónico cuyo modelo sociocultural y político se inspira en la agenda de los movimientos de clase media europeos y estadounidenses. En los años 1990, entramos, según González Villareal (2002: 16), en el periodo de la posliberación. Con la influencia de los estudios feministas, de género y queer, se cuestiona la construcción hegemónica de un sujeto gay, se desnaturalizan las categorías masculino-hombre, femenino-mujer, y homosexual, y se fortalecen las prácticas vinculadas con lo sexual.

La liberación, dice González Villareal, "no nos liberó del sexo, nos ató más a él” (2002: 17).

10 La traducción al español es mía, a partir de la traducción al francés por Didier Eribon de la conferencia "construire des significations queer" que Eve Kosofsky Sedwick dio en inglés en el marco del coloquio "Les études gay et lesbiennes", París, Centre Georges Pompidou, 23-27 de junio de 1997. 
Efectivamente, la identidad homosexual, desde las primeras ficciones eróticas o los primeros relatos de invertidos difundidos en Europa en el siglo XIX, integra el sexo y las prácticas (homo)sexuales como rasgo identitario determinante. Y este aspecto no ha cambiado ni con la liberación homosexual durante la que nace la figura del gay - el homosexual autoasumido que toma la palabra y se politiza一, ni en la etapa postgay (años 1990) en la que surge la figura del sujeto queer, preocupada por la circulación del deseo y la ampliación de las posibilidades eróticosexuales percibidas y afirmadas como prácticas de subversión política.

\section{LA NOCIÓN DE SCRIPT:}

\section{GUIONES INTRAPSÍQUICOS, GUIONES} INTERPERSONALES Y GUIONES CULTURALES La noción de script permite asentar bases epistemológicas para entender cómo el sujeto organiza su identidad y su comportamiento sexual en los espacios de la intimidad y de las interacciones sociales.

Para Gagnon, toda conducta sexual presupone un esquema cognitivo estructurado (script) fuera del cual los actores no podrían reconocer el carácter potencialmente sexual de la situación (1999: 73). Las prácticas sexuales pueden ser observadas como procesos en los cuales se encuentran los individuos, sus relaciones interpersonales y la cultura. El script es "la forma organizada de convenciones mutuamente compartidas que permite a dos actores o más participar en actos complejos que implican relaciones de dependencia mutua" (1999: 73). El autor clasifica los guiones sexuales según tres niveles: nivel intrapsíquico, nivel interpersonal de la interacción social y nivel del guión cultural (1999: 76).

Los guiones intrapsíquicos, cuyos orígenes son diversos (fragmentos de deseos, de recuerdos, de fantasía) corresponden al contenido de la vida mental y son parcialmente el resultado de las prescripciones de los guiones culturales. Los guiones interpersonales, en los que el sujeto" es un actor que responde a las expectativas de otras personas, corresponden al plano de las interacciones sociales (encuentros, rituales, seducción, rechazo, excitación). En cuanto a los guiones culturales, pueden considerarse como tipos de reglamentos que operan en la vida colectiva y la regulan en un momento dado; éstos son sistemas semióticos que especifican el contenido y las prácticas socialmente aceptables -o grupalmente aceptables, en el caso de la subcultura gay - de cada rol prescripto por las instituciones, los dispositivos institucionales o por la comunidad alternativa de pertenencia.

La división tripartita de los guiones sexuales permite dar cuenta de la compleja y dinámica interrelación entre sujeto, sociedad y cultura. En la interfaz entre la cultura y la vida mental, el sujeto es espectador, crítico y corrector, en la medida en que, señala Gagnon, los materiales de los guiones culturales son importados en los guiones intrapsíquicos. En la interfaz entre la interacción social y la vida mental, el sujeto es actor, crítico y dramaturgo. No hay, precisa el autor, interfaz directa entre la cultura y las interacciones sociales ya que los efectos de la cultura son mediatizados por la vida intrapsíquica.

11 Gagnon emplea el término de "individuo", pero para nuestro propósito preferimos el término de "sujeto". 
El consumo de pornografía es una práctica ampliamente integrada en la diversa comunidad gay. Basta con entrar en una librería LGBTI para atestiguarlo: siempre hay uno o varios libreros con videos, revistas o libros de carácter pornográfico. La pornografía forma parte de la (sub)cultura gay; cobra, por tanto, importancia en la configuración de guiones (sub)culturales y, por consiguiente, también en la estructuración de guiones intrapsíquicos productores de placer sexual. Esto explica en gran medida por qué no resultó muy difícil encontrar informantes homosexuales dispuestos a hablar de su relación con el consumo de pornografía.

\section{REACCIÓN DE LOS SUJETOS (HOMO)ERÓTICOS} FRENTE A LA ENTREVISTA SOBRE PORNOGRAFÍA

Como lo mencioné previamente, la elección de los entrevistados se hizo a partir de mi lista personal de contactos en Facebook. Envié diez correos -Inbox en la terminología de Facebook - en los que explicaba la naturaleza de la entrevista, precisaba que los informantes no estaban obligados a contestar a todas las preguntas, y dejaba la posibilidad de que éstos pudieran interrumpir la entrevista si no deseaban continuar con ella. Para mi sorpresa —-debido al carácter íntimo de la entrevista, presupuse que no habría muchas respuestas favorables-, el $80 \%$ de las personas contactadas aceptó inmediatamente. Algunas de ellas, incluso, propusieron ponerme en contacto con amigos suyos. Nadie rechazó ninguna pregunta; nadie abandonó la entrevista. Algunos entrevistados, por iniciativa propia, relataron anécdotas, gustos y prácticas sexuales de gran intimidad, lo que deja pensar que hablar de las prácticas sexuales personales no planteó aparentemente ninguna inhibición. Considero que fueron tres los factores que motivaron esta actitud. Primero, el hecho de que, previamente a las entrevistas, hubiera interacción vía Facebook; la mayoría de los entrevistados eran "amigos míos virtuales". Segundo, el hecho de que el entrevistador también forme parte de la amplia y diversa comunidad "homosexual" y comparta experiencias semejantes, contribuyó a que los entrevistados actuaran "con toda confianza". Tercero, al hablar de una sexualidad asumida, los entrevistados reactualizan momentos placenteros en el marco de un proceso sexo-identitario satisfactorio.

La mayoría de las entrevistas, todas grabadas con permiso de los informantes, se llevaron a cabo en la sala de mi domicilio, con café, té o agua y pan dulce, lo que contribuyó a darles un carácter más informal y amistoso. Seis de ellas fueron realizadas en los domicilios de los entrevistados, en situaciones similares (en la sala, con grabadora, café, té o agua y galletas). Durante las entrevistas, sin que fuera una regla preestablecida, el entrevistador no habló de sus experiencias sexo-eróticas ni los entrevistados le hicieron preguntas al respecto.

Antes de abordar la temática del consumo de pornografía, pregunté los datos civiles (fecha y lugar de nacimiento, tipo de familia en la que el informante nació y creció, oficio, lugar de residencia). En un segundo tiempo, pregunté a los informantes cómo se definían desde un punto de vista sexo-genérico y respecto a la orientación sexual.

Cuando contestaban que se definían como homosexuales o gay, les preguntaba desde cuándo y si fue fácil o difícil asumir tal orientación en el 
ambiente familiar. Esta pregunta permitía colectar información sobre los eventuales procesos de resistencia a una subjetivación heterosexual, así como sobre los procesos de subjetivación (homo) erótica.

Cuando contestaban que se negaban a definirse porque rechazaban las etiquetas (sólo dos personas), les preguntaba, con el objetivo de ver cuáles eran las estrategias discursivas de resistencia o de cuestionamiento de las normas clasificatorias, si así había sido siempre. En su gran mayoría, los entrevistados se definieron como hombre homosexual o gay. En un caso (José) la respuesta fue: "me defino como puto" porque las palabras "homosexual" y "gay" "no me gustan". En un tercer tiempo, abordé el consumo de pornografía invitando primero a recordar una imagen o un texto que provocó una fuerte excitación.

Uno de los aspectos más relevantes de las entrevistas es lo que Bourdieu llamaba la "ilusión biográfica", un proceso que consiste en relatar su vida como si fuera una historia, un relato organizado cuyo objetivo es dar coherencia y orientación intencional a los acontecimientos narrados (Bourdieu, 1986: 6970). Este aspecto, que no desarrollaremos aquí, me parece ser el resultado tanto del esfuerzo de síntesis narrativa al que se sometieron inconscientemente los entrevistados para contestar de forma breve y exhaustiva, a las preguntas, como de la interacción con investigador en busca de material para un ensayo.

Hubo posiblemente, de parte de los entrevistados, la selección de guiones intrapsíquicos e interpersonales percibidos como material de interés para un trabajo académico. Esto lo deduzco de una entrevista en particular, durante la que el informante estaba preocupado por el hecho de que no le hiciera muchas preguntas. En varios momentos me preguntó si lo que decía correspondía con lo que yo estaba esperando. Le precisé que no estaba esperando una respuesta concreta y preestablecida.

Soy consciente de que los entrevistados, al producir una "narración", es decir, al elaborar y organizar, aunque de manera espontánea, una diégesis ${ }^{12}$ para dar cuenta de experiencias vividas que tuvieron lugar en un tiempo anterior a la entrevista, crean un desfase más o menos importante entre el yo enunciador y el yo enunciado. Como en cualquier proceso de ficcionalización, en ese desfase hay, naturalmente, diversas interferencias como la eliminación de momentos disfóricos, reelaboración mitificada de un pasado, proyección de fantasías, etcétera. No obstante, dado que el yo enunciado acarrea consigo tanto el proceso de socialización por el que pasó como las marcas de un habitus personal o grupal, el testimonio de los entrevistados es un material valioso para llevar a cabo este tipo de trabajo; esto es, como lo señala Rodrigo Laguarda, citando a Garay, el "yo reflejado en las entrevistas es un yo participativo en la dinámica social" (2009: 34).

\section{INCIDENCIA DE LOS GUIONES CULTURALES EN LOS GUIONES INTRAPSIQQUICOS E INTERPERSONALES DEL SUJETO (HOMO) ERÓTICO}

Antes de percibirse o autodefinirse como sujeto (homo)erótico, el individuo pasa por un proceso de sexualización a través del cual interioriza que está dotado de un cuerpo sexuado (Peña Sánchez

12 Entiendo por diégesis a la vez el contenido del relato y las modalidades de construcción formales del mismo. 
y Hernández Albarrán, 2011: 135). Dicho proceso se da en contextos sociales, culturales e históricos específicos y está marcado por las normas en vigor respecto a la articulación entre sexo, género y orientación social. Desde su nacimiento, al individuo se le forma para comportarse sexualmente en adecuación con los modelos hegemónicos (hombre-masculino-heterosexual, mujer-femeninaheterosexual); se trata de una educación que inicia generalmente en el seno familiar. "No nacemos como seres sexuales”, dice el antropólogo Joan Vendrell, "nos convertimos en tal cosa a lo largo de un proceso de socialización donde se nos va 'sujetando' a una serie que podemos llamar 'identidades': de género y sexuales" (citado por Peña Sánchez y Hernández Albarrán, 2011: 135).

Bajo la interpretación -en el sentido teatral o performativo de la palabra- de un abanico de instancias como lo son la familia tradicional, el personal docente, los sacerdotes, los medios de comunicación, etc., los guiones culturales dominantes respecto a la sexualidad normada tienen como función la de crear guiones intrapsíquicos e interpersonales en conformidad con las reglas sociales. La operatividad de los guiones culturales en individuos que sienten atracción por individuos del mismo sexo y género o que transgreden los roles de género socialmente asignados dependerá de dos factores, según observamos a la luz de las entrevistas realizadas. El primero tiene que ver con el grado de explicitación y de condena de las conductas (homo)eróticas o de las transgresiones genéricas en el entorno del individuo: cuanto menos se mencionan -o cuanto más se silencian-, menos probabilidades tienen de ser interiorizadas como elementos negativos. El segundo factor se vincula con el grado de concientización, y por ende de normalización, del sujeto sexuado respecto a la estigmatización de dichas conductas. Los siguientes ejemplos ilustrarán lo expuesto.

Alberto (76 años): El término homosexual no formaba parte de la terminología ni familiar, ni entre compañeros. Era algo velado. No creo que se haya pensado algo inmoral o indebido, sencillamente no se hablaba.

Omar (69 años): [...] uno empieza a darse cuenta de la sexualidad en la adolescencia, pero aun niño yo me daba cuenta de que a mí me gustaban los niños, no las niñas. Fui muy precoz en el jugueteo con mis compañeros, les agarraba la pilila en el kínder, y esas cosas, yo no sabía que tenía algo particular.

Lino (27 años): [...] yo no sabía qué era la homosexualidad o ser gay. Pero sí recuerdo cuando era súper chavito, tipo 6-7 años, recuerdo que me llamaba la atención un señor, o sea me gustaba, pero yo no sabía qué era, yo no sabía qué era la homosexualidad. Ya pasando los años, obviamente me entero. Uno se hace consciente de muchas cosas y pues, ya sabía que era la homosexualidad, entonces como en la primaria, finales de la primaria, empezando la secundaria, yo me di cuenta que era gay, homosexual.

Javi (24 años): Primero yo me asumí como bisexual, cuando tenía como 13 años, porque todavía sentía atracción por las mujeres y por los hombres. Estaba en esta etapa de ver qué era lo que me gustaba y después me definí como gay cuando me di cuenta de que me gustaban más los hombres y que disfrutaba más las relaciones con hombres.

Mauricio (28 años): [...] íbamos [el informante y su tío] a los vapores donde estaban los adultos y para mí era una fascinación ver muchos hombres desnudos hasta que descubrí, creo que fue la primera vez que sentí vergüenza por lo que me gustaba, porque me 
daba cuenta que me excitaba viendo y dije un día, van a ver que me excité y me van a correr de aquí. Yo tenía entonces 11 años y decidí ya no volver más.

Guillermo (34 años): Mi sexualidad se despertó mucho como a partir del travestismo, antes de que yo definiera que me gustaban los hombres. Fue más como asumirme en otro género, o sea como que a partir de ahí yo empecé mi sexualidad. [...] Mi primer recuerdo es que me dejaban solo y tenía un disco de Madonna y vi unos tacones que usaba. Me fui por los tacones de mi mamá. Me pareció como arriesgarme a tocar algo que no es mío, como cuando vas a romper algo. Me los puse, me fui caminando. Me acuerdo de mis piecitos y me veo en el espejo y ahí tuve conciencia de que yo era hombre, o sea me di cuenta que estaba rebasando mi género, que estaba haciendo algo malo. Ahí tomé conciencia. [...] Me espantó tener conciencia tan chavito de algo. Yo no entendía qué, pero era un secreto. Si me veían iba a estar mal. Yo era niño, no niña.

De los extractos citados, podemos sacar las siguientes conclusiones:

a) Los guiones culturales heterocentrados no inducen sistemáticamente guiones intrapsíquicos de la misma índole. Existe, por consiguiente, un desfase entre aquellos y éstos, particularmente cuando el individuo, en su niñez, siente atracción por individuos del mismo sexo. En el caso de Javi, los guiones culturales inducen la idea de una bisexualidad que parece articular la orientación sexual normada con la orientación sexual deseada y permitir una transición menos traumática de la primera (hegemónica) a la segunda (minoritaria). Guillermo declara al respecto: "fueron unos años de estar como en los dos lados. Creo que me daba miedo asumirme gay y era como entrar poco a poco. Sentía que siendo bisexual me costaba menos trabajo."

b) El déficit de información respecto a las "transgresiones" sexuales, como lo confirma el testimonio de Omar ("yo no sabía que tenía algo particular") y el de Lino (“yo no sabía qué era la homosexualidad") contribuyen, o bien al disfuncionamiento de la operatividad de los guiones culturales en tanto dispositivos disciplinarios de cuerpos heterocentrados, o bien a la postergación de una toma de conciencia identitaria "disidente".

c) El orden de género difundido por los guiones culturales puede ser una fuente de goce sexual cuando se transgrede dicho orden. El testimonio de Guillermo es bastante ilustrativo de cómo se puede gozar con el género. Sus primeras emociones sexuales, tal y como las recuerda, provienen de su transgresión genérica ("Mi sexualidad se despertó mucho como a partir del travestismo, antes de que yo definiera que me gustaban los hombres") y no de un deseo sexual hacia otra persona.

Los guiones culturales actúan, sin embargo, de manera activa en la configuración del superyó del sujeto (homo)erótico, como revela el testimonio de Mauricio ("sentí vergüenza por lo que me gustaba") o el de Guillermo ("Yo era niño, no niña"). El desfase entre los guiones culturales dominantes y los guiones intrapsíquicos "disidentes" provoca en la mayoría de los sujetos un problema (un desconcierto o una contradicción) que tendrán que resolver de una manera o de otra. Esto puede conducir, bien a un proceso de resignificación valorativa (sujeto [homo] erótico asumido como tal), bien a una negación, temporal o definitiva, de una identidad (homo) erótica. 
Asumir una subjetividad homosexual o de disidencia sexual depende en parte del grado de flexibilidad de los guiones culturales dominantes. Estos se inscriben en determinados contextos sociohistóricos y se subordinan a lo que, en dichos contextos, está permitido pensar o hacer. No es lo mismo identificarse como homosexual en tiempos de represión y de estigmatización (antes de los años 1970), que hacerlo en tiempos de liberación (años 1970-1990) en los que los grupos militantes intentan construir los contornos identitarios de un sujeto homosexual "liberado" de la estigmatización dominante. Tampoco es lo mismo reivindicar, en años posteriores a 1990, una postura queer de libre y movediza circulación del deseo que rompa con todas las asignaciones hegemónicas respecto a sexo, género y orientación sexual. A continuación expondré algunos ejemplos.

Omar tiene 69 años. Nació en una familia "muy tradicionalista que había emigrado del estado de Jalisco huyendo de la guerra cristera. Una familia sumamente conservadora, católica." Es alto - mide alrededor de 1.90 metros-, delgado y de aspecto "varonil". ${ }^{13}$ A la pregunta, ¿cómo te defines desde un punto de vista sexo, género, orientación sexual?, responde: "Homosexual, $100 \%$ sin ninguna duda." De niño le gustaban los niños, "no las niñas". En sus primeros guiones intrapsíquicos están los juegos sexuales con niños en el kínder y masturbaciones provocadas por fantasías con chicos. Omar comenta:

$13 \mathrm{Si}$ preciso este rasgo "varonil" es para señalar que la identificación al género masculino hegemónico tiende a hacer invisible, en el espacio social, la orientación homosexual, más evidente en individuos "afeminados" según la imaginería colectiva.
Mi primera relación sexual fue a los 26 años, entonces como el ambiente era tan opresivo yo decidí negar mi sexualidad. Mi sexualidad consistía en masturbarme nada más y hacer fantasías sobre chicos, pero sin aceptar que yo era homosexual. Había un bloqueo mental absoluto muy franco y en el fondo yo sabía, esto no es cierto, tú eres homosexual, pero jamás lo hacía, no pasaba de esa parte del subconsciente al consciente $[. .$.$] "Es una práctica de maricones, pero$ yo no lo soy, a mí me gustan los hombres, pero yo no soy homosexual, porque el hecho de aceptarlo era muy traumático" [...] Tenía un sentimiento religioso muy fuerte, muy difícil de vencer, la idea de estar en falta, en pecado, la condenación eterna y esas cosas.

El extracto muestra cómo operaban en el sujeto los guiones culturales dominantes en la sociedad mexicana de los años 1950. El peso de las prescripciones y de las proscripciones religiosas, a las que se añade la estigmatización social de la homosexualidad, dificultan, a partir del momento en que el sujeto se da cuenta de que su deseo contraviene las/sus reglas sociomorales, tanto el propio reconocimiento dentro de la categoría estigmatizada, como llevar a cabo guiones interpersonales. La solución transitoria para Omar fue evitar, hasta los 26 años, la interacción social en materia de sexualidad, recluyéndose en un onanismo socialmente invisible.

A los 26 años conoce a una pareja hombre con quien tiene relaciones sexuales durante tres años, pero proyecta casarse y tener hijos con una mujer que fue su novia durante dos años y medio. La relación con esta "novia", exenta de acercamiento sexual como lo precisa el entrevistado, y la perspectiva de casarse lo sumergen en una situación angustiosa. Los guiones culturales que ha adoptado (o interiorizado) 
como valores sociales estructurantes entran en contradicción con sus guiones intrapsíquicos. No sólo le plantean un problema que le cuesta trabajo solucionar sino que provocan un sentimiento de angustia y de cierto sufrimiento. Hallará una solución recurriendo al psicoanálisis. Afirma:

Tenía un sentimiento religioso muy fuerte, muy difícil de vencer [...] y realmente pude quitármelo a través del psicoanálisis, si no fuera por eso, ¿quién sabe que hubiera sido de mi vida? [...] Hice una terapia lacaniana [...] y entonces me olvidé del plan heterosexual, me olvidé de la religión, me olvidé del pecado. Claro, son demonios que te visitan ocasionalmente. Pero gracias a eso fue que pude hacer una vida libre.

El psicoanálisis le ayudó a distanciarse de los elementos culturales que lo orientaban hacia guiones interpersonales en total contradicción con los elementos intrapsíquicos productores de placer sexual.

En un marco temporal similar al de Omar, el ejemplo de Alberto parece presentar un caso de configuración (homo)erótica asumida sin conflicto aparente. Alberto nació en 1937, tiene 76 años y es de aspecto "varonil". Se crió "en una familia tradicional, muy amorosa, muy dedicada la madre a la casa y el padre a ser proveedor". A la pregunta, ¿cómo te defines desde un punto de vista sexo, género, orientación sexual?, contesta:

Definitivamente soy homosexual, pero un homosexual muy raro, porque déjame decirte una cosa, no me gusta el miembro, no me gusta verlo, los genitales del hombre se me hacen la cosa más fea del hombre [...] A veces digo que a lo mejor no fui gay, pero por falta de una orientación adecuada ahí me quedé por comodidad y lo he disfrutado enormemente, ni siquiera concibo la idea de tener una relación con una mujer.

Los guiones intrapsíquicos de Alberto rompen con los guiones culturales dominantes - de hecho también con los del habitus grupal gay-, pero esto no parece haber provocado ningún tipo de incidencia negativa en la configuración de los primeros. Asumir su orientación sexual, que por falta de un término adecuado denomina "homosexualidad", no fue nada difícil ni traumático: "asumir la condición de homosexual, que quizá para muchos es un trauma, para mí no lo fue porque esta actividad [escultismo] que generaba el grupo satisfacía mi necesidad de compañía masculina." La definición implícita que Alberto tiene de la sexualidad parece conectar el placer con el hecho de estar "en compañía masculina", sin que esto suponga contacto sexual. Posiblemente, al no centrar su sexualidad en los genitales, al no desear ni penetrar ni ser penetrado, Alberto estaba menos expuesto, cuando era niño y adolescente, a una identificación homosexual. Su deseo de estar en un grupo de hombres "masculinos", de establecer lazos fuertes de amistad con ellos, no era percibido como conducta condenable. Su identidad erótica no entraba en tensión con los guiones culturales dominantes.

Alberto se define como "un homosexual muy raro" porque no entra dentro de los cánones gay hegemónicos. ¿Cómo se configuran sus guiones intrapsíquicos? ¿Cómo rescata Alberto, con la distancia temporal, algunos fragmentos de dichos guiones?

En su relato aparecen primero unas películas "que le decían en episodios" en las que el héroe, 
"muy gallardo y varonil", llevaba botas. Las botas van a convertirse en un fetiche imprescindible de su erotismo: "todas mis relaciones físicas sexuales, si no la hacía yo con unas botas de montar, no se realizaban." Otro aspecto que menciona es el hecho de que los héroes que lo fascinaban eran frecuentemente torturados y estaban desnudos o semidesnudos. En otro momento, Alberto explica de dónde viene su fascinación por la tortura como ingrediente erótico. A los 6 ó 7 años descubre, en la iglesia, la imagen de un cuerpo crucificado: "la verdad yo no asistía a la misa más que para estar viendo aquel individuo que es Jesucristo según la religión católica.” Otra fuente de excitación son las novelas del Oeste "donde los indios agarraban a los soldados o a los vaqueros y le hacían cuanta diablura te puedas imaginar y eso [...] causaba una enorme excitación".

Para Alberto "el mayor órgano sexual del hombre es la piel" y piensa que "es un desperdicio horrible concentrar la sexualidad en los genitales o en el ano". "Cuando sabes manejar las cosas", agrega, "puedes hacer que la gente sienta placer". Sus prácticas eróticas escapan a los estereotipos culturales de la industria pornográfica gay. Vemos cómo, en tanto sujeto, organiza dramatúrgicamente sus guiones interpersonales a partir de la materia intrapsíquica y escenifica sus puestas en escena. En diversos momentos comenta las carencias y la falta de apertura imaginativa de las producciones porno gay mainstream. Las prácticas eróticas de Alberto, que él mismo anuncia como raras al principio de la entrevista, se insertarían perfectamente en las exploraciones que está llevando a cabo la nueva generación queer. De cierto modo, Alberto es un sujeto queer avant la lettre.
Javi es un ejemplo de esta generación queer. Nació en 1989, cuando en Estados Unidos empezaba a gestarse la teoría queer. Tiene 24 años y es estudiante de maestría en artes visuales en área de arte público. Su aspecto es el de un joven andrógino. A la pregunta, ¿cómo te defines desde un punto de vista sexo, género, orientación sexual?, responde:

Eso es complejo, porque yo más bien estoy en una postura muy múltiple. Como tal, una definición no he encontrado, porque yo he transitado en distintos polos de definición a lo largo de mi vida. Primero yo me asumí como bisexual, cuando tenía como 13 años porque todavía sentía atracción por las mujeres y por los hombres; estaba en esta etapa de ver qué era lo que me gustaba y después me definí como gay cuando me di cuenta que me gustaban más los hombres y que disfrutaba más las relaciones con hombres. Eso fue a los 18 . De los 18 a los 22 estuve como en esa identidad gay completamente. Y después de los 22 empecé a adentrarme en estos mundos académicos que tienen que ver con lo queer y lo ambiguo y con lo andrógino. [...] De repente empecé a interesarme por lo trans, me empecé a interesar por hombres, por mujeres [...], entonces decía yo: ¿dónde me identifico? No puedo ser heterosexual, porque no sólo me gustan las mujeres, ni los hombres, ni en gay porque no sólo me gustan los hombres, ni en bisexual. [...] Por otro lado, estaba como la onda de mi estética andrógina, entonces me empezó a interesar lo andrógino, pero no me quería definir sólo como andrógino, y luego, actualmente, yo estoy trabajando con la identidad trans pero no una identidad trans como la que ya conocemos [...] sino más bien yo estoy definiendo mi propia identidad transgénero como una identidad alternativa de búsqueda y en constante movimiento. 
A continuación, reproduzco un breve diálogo:

Yo: Por ejemplo, ¿varón, mujer, son categorías que aplican o no?

J: No, realmente no.

Yo: ¿Masculino, femenino?

J: Masculino, femenino, sí, eso sí aplica porque considero que esas son dos categorías que tenemos a nivel de la realidad, lo masculino y lo femenino, el mundo se ha estructurado así, de una manera sexista que únicamente te da acceso a dos géneros y a dos sexos y a dos formas de ser y de comportamiento masculino o femenino, pero a mí realmente como que me interesa permanecer mucho en el margen de los géneros.

En el relato de Javi queda clara la interrelación de los guiones culturales y los guiones intrapsíquicos en su construcción como sujeto erótico. Antes de entrar en el mundo académico y de descubrir los aportes de la teoría queer sobre sexo, género y sexualidades, sus primeros guiones intrapsíquicos están impregnados de las categorías identitarias sexuales dominantes: pasa por una primera etapa en la que se define como bisexual, luego se percibe como gay, y finalmente, en una tercera etapa, con base en la teorización queer, sale de las etiquetas hegemónicas. La sexualidad constituye un campo de exploración del cuerpo y del deseo que rompe con los límites generalmente asignados. Las categorías varón/mujer así como homosexual, heterosexual y bisexual no aplican en su elaboración discursiva. En su caso parece que la teoría queer contribuyó a deconstruir las antiguas categorías y a construir un nuevo sujeto erótico. Particularmente interesante resulta su relato de una fiesta de cumpleaños que se transformó, según sus palabras, en un acto micropolítico:
Hice una fiesta donde convoqué a todos mis amigos con los que comparto esta ideología, no tener definición y estarla buscando, estar experimentando [...] Les dije que fueran de pijama [...] Lo que pasó en esa fiesta fue muy interesante y muy inesperado, como muy performático, porque llegaron demasiadas personas en pijama súper diversas, pero en algún momento de la noche, los cuartos estaban abiertos [...] entonces nos empezamos a meter a los cuartos y empezamos de la nada a experimentar con nuestros cuerpos; era como un juego, entre te ves muy bien, caricias, besos, y había toda clase de placer y todo terminó en que en los cuartos estaban aconteciendo pues como orgías, pero no estas orgías del discurso porno, donde todos están desnudos y se están penetrando, sino que aquí [...] algunos sí estaban experimentado eso de la penetración y del sexo oral, pero otros estábamos experimentando las caricias y estábamos experimentando el sonido, diciendo cosas en el oído muy cachondas, intercambiándonos las pijamas, y en todos los cuartos estaba pasando eso. Ya después en el centro de la pista donde todo el mundo estaba bailando, nos dimos cuenta que todo el mundo estaba ya sin ropa o con muy poca ropa, pero haciendo actos micropolíticos, sin pensar que era un acto micropolítico, pero estaba aconteciendo, como tres chicos besándose desnudos juntando sus penes, o dos chicas por acá quitándose la playera y poniéndose diurex en los pechos y al mismo tiempo bailando y disfrutando de la fiesta [...] Me interesó mucho esta onda como del placer político llevado a una colectividad y como esta onda de romper con esta cuestión que el acto sexual solamente puede ocurrir entre dos o tres personas. ¿Por qué no puede ocurrir de repente entre 15 ó 16 ?

La sexualidad, la experimentación con el cuerpo erotizado en interacción social con otros cuerpos diversos es interpretada en tanto "acto micropolítico"14 de subversión de los guiones

14 Implícitamente, Javi parece establecer una diferencia entre acto macropolítico y acto micropolítico. La fiesta, 
culturales dominantes. Asistimos al surgimiento de un nuevo sujeto erótico que ha dejado de identificarse como homosexual o bisexual y que intenta cuestionar los límites diferenciadores y excluyentes de los marcadores dominantes sexogenéricos, aunque de vez en cuando, para expresar la postura subversiva, Javi recurre a un léxico y una sintaxis de la categorización genérica dominante ("chicos desnudos juntando sus penes", "chicas quitándose la playera y poniéndose diurex en los pechos"). Pero está presente la preocupación por neutralizar sus efectos en el discurso a través del empleo de palabras que anulan semánticamente la distinción genérica ("personas", “cuerpos").

En la construcción y la afirmación nítida de un sujeto (homo)erótico, que ha conseguido asumir sus guiones intrapsíquicos, en la deconstrucción queer de ese mismo sujeto (homo)erótico, en el enunciado "homosexual $100 \%$ sin ninguna duda" de Omar y en el enunciado "me interesa permanecer en el margen de los géneros" de Javi, están implícitamente las marcas de luchas de representaciones y de resignificaciones historizadas. Los guiones culturales dominantes respecto a la sexualidad, exclusivamente heterocentrados y homofóbicos de los años que precedieron al periodo contracultural de liberación sexual (década de 1960; época en la que nacieron Omar y Alberto), entraron

aunque llevada a cabo en un espacio "privado", se convierte en un espacio micropúblico en el que se reúnen personas que, sin que fuera un objetivo previo, estuvieron experimentando y descubriendo relaciones sexo-sensuales fuera del marco convencional de los guiones culturales dominantes sobre sexualidad (acto sexual genitalizado llevado a cabo por dos acompañantes con la misma orientación sexual). El acto micropolítico consistió en romper con la rigidez de los paradigmas sexuales convencionales y políticamente aceptables. en tensión con los guiones alternativos propuestos por los movimientos feministas y homosexuales de los años 70. A partir de ese momento, como alternativa a los guiones culturales dominantes, surgió y empezó a generalizarse una serie de guiones "subculturales" gay que se difundieron y se adoptaron en lugares de sociabilidad como los antros, las fiestas privadas o los diferentes talleres de intercambio cultural. Funcionaron, en las décadas 1980-1990 - y continúan funcionando- como referentes valorativos de la identidad homosexual, ${ }^{15}$ no sólo dentro de la comunidad gay, sino también, de forma parcial, en la manera de representar y de considerar las conductas homosexuales en los guiones culturales dominantes -que siguen, sin embargo, fuertemente marcados por el heterocentrismo. Estos guiones "subculturales", como productores de representaciones sociales, participaron, a su vez, de la construcción de una hegemonía homonormativa e indujeron conductas estereotipadas que adoptó y reprodujo un amplio conjunto de homosexuales de clase media urbana. Esta homonormatividad es la que están cuestionando y deconstruyendo los movimientos queer, como revela, por ejemplo, el discurso de Javi, uno de los informantes.

\section{LUGAR Y FUNCIÓN DE LA PRODUCCIÓN PORNOGRÁFICA EN LA ELABORACIÓN DE LOS GUIONES INTRAPSÍQUICOS E INTERPERSONALES}

15 De acuerdo con Núñez Noriega, entendemos por identidad homosexual "un sentimiento de pertenencia (identificación que tiene como sustento el habitus grupal) y diferencia (respecto a los bugas, los normales, los heterosexuales)" (1999: 180). 
En las entrevistas destacan dos tipos de imágenes pornográficas: las que podríamos llamar “imágenes porno-gay intencionales" y las "imágenes pornificadas". ${ }^{16}$ Las primeras están fabricadas desde el polo de la producción industrial con una intención pornográfica explícita. Corresponden a la pornografía mainstream y son las mayoritariamente consideradas por los entrevistados. Las segundas, cuya carga porno-erótica es el resultado de una operación mental que ejecuta el sujeto (homo) erótico, pertenecen a géneros y soportes extrapornográficos (cuentos infantiles, cuadros pictóricos, esculturas, historietas, películas comerciales para todo público, etcétera). Son minoritarias en las entrevistas, pero participan, al igual que las imágenes pornográficas mainstream, en la constitución de guiones intrapsíquicos e interpersonales.

\section{PORNIFICACIÓN DE IMÁGENES EXTRA-PORNOGRÁFICAS}

La pornificación de las imágenes extra-pornográficas se da mayoritariamente en contextos en los que la pornografía es aún marginal respecto a difusión y grado de tolerancia social (1940-1960). Es abordada de manera detallada y con varios ejemplos por dos entrevistados mayores (Alberto, nacido en 1937 y Omar, en 1944).

Para Alberto, son varios los recuerdos de imágenes que provocaron una fuerte excitación: un cuento infantil de "un niñito", el cuento de Los tres cochinitos, las películas "en episodios" tipo Flash Gordon y las novelas del Oeste. En el cuento del "niñito" lo que causa excitación a Alberto, a la edad

16 Tomo prestados los términos "pornificar" y "pornificación" del ensayo Testo Yonki de Beatriz Preciado (2008: 42). de cinco o seis años, es que al niñito "lo arrojaban a una alberca atado", "eso", dice "me causó una excitación extraordinaria". En Los tres cochinitos, son esencialmente las escenas en que el lobo es torturado: "lo ataban y con una máquina que tenía unos cepillos, una rueda, ponían al lobo bocabajo y con aquella máquina le golpeaban.” En las películas de Flash Gordon, Alberto se fija en el aspecto físico del héroe ("hombre muy gallardo", "muy varonil") $\mathrm{y}$ en un elemento del vestuario que va a marcar su sexualidad: las botas. Éstas se van a convertir en un accesorio imprescindible para llevar a cabo los encuentros sexuales. Las novelas del Oeste le provocan excitación esencialmente cuando los indios "agarraban a los soldados o a los vaqueros y le hacían cuanta diablura te puedas imaginar". En el caso de Alberto, los guiones intrapsíquicos, marcados por su gusto por las escenas de tortura, contribuyen a una fuerte pornificación de productos culturales extra-pornográficos que, a su vez, alimentan y amplían sus fantasías sexuales. Las imágenes pornificadas funcionan como materialización visual, o "alegorización” de ciertos aspectos y orientaciones de su sexualidad ya que revelan, en el sentido fotográfico de la palabra, gustos y comportamientos latentes.

Omar recuerda dos tipos de imágenes: los actores hollywoodenses (James Dean, "sin camisa") y mexicanos (Julio Alemán, "que era un hombre muy guapo y tenía un lindo cuerpo") del cine de los años 1950-1960 y las historietas tipo "Los halcones negros". A propósito del actor Julio Alemán, dice: “en una película que se llamó Los hermanos del hierro $^{17}[\ldots]$ él salía desnudo, muy rápidamente, 17 Los hermanos del hierro es una película mexicana de 
porque salía corriendo, pero bueno, esa imagen a mí me dejó perturbado por días enteros y todas las noches me masturbaba divinamente." Respecto a las historietas, Omar cuenta que "había revistas que nada tienen que ver con pornografía, pero tienen que ver con masculinidad exacerbada". En una de ellas, "eran siete hombres que vivían en un castillo y se dedicaban a hacer el bien. Siempre tenían los uniformes apretados, unas musculaturas maravillosas. Era muy excitante porque eran siete hombres que vivían juntos en un castillo."

En los dos testimonios, independientemente del tipo de fantasías evocadas, lo que llama la atención es la valorización de ciertos códigos de la masculinidad hegemónica (musculatura, aspecto "muy" varonil, uniformes apretados, masculinidad "exacerbada"). Uno de los elementos sexualmente excitantes para los entrevistados es la virilidad de los cuerpos masculinos que presentan una perfecta y marcada coherencia entre sexo y género tal y como está codificada en las normas sociales heteronormativas - la mayoría de las imágenes pornificadas mencionadas por los entrevistados provienen, en efecto, de producciones heterocentradas. Leo Bersani, a propósito de la fascinación gay por lo que él llama "el estilo macho" o "el machismo" (1995: 95-97), apunta:

[...] el deseo sexual de unos hombres por otros no puede ser tan sólo una especie de atracción cultural neutra hacia una idea platónica del cuerpo masculino. El objeto de deseo implica necesariamente una definición socialmente determinada y de hondo calado de lo que es ser hombre [...] la interiorización es parte constitutiva del deseo homosexual que, como todo deseo sexual, 1961, dirigida por Ismael Rodríguez. combina y confunde pulsiones de apropiaciones y de identificación con el objeto del deseo (1995: 96).

Las observaciones de Bersani inducen la idea de que los guiones intrapsíquicos de los sujetos (homo)eróticos están inconscientemente atravesados por las normas de género dominantes e impregnados de las representaciones culturales hegemónicas: hombres muy masculinos $v s$ mujeres muy femeninas, lo que refuerza, reproduciéndolo, el binarismo sexogenérico socialmente establecido. Para Alberto y Omar, asumir una identidad homosexual consiste no tanto en cuestionar los códigos del orden de género, sino en resignificar valorativamente una categoría estigmatizada y creada por el heterocentrismo, resignificación que se elabora a partir de los códigos genéricos del propio heterocentrismo. De esta manera, su identidad homosexual está lejos de ser una identidad política, tal y como se entenderá en los años de liberación homosexual. De acuerdo con Bersani, una verdadera identidad política gay supondría "una lucha no sólo contra las definiciones de la masculinidad y de la homosexualidad tal y como son reiteradas e impuestas por los discursos sociales heterosexistas, sino también contra esas mismas definiciones tan seductora como fielmente reflejadas por aquellos cuerpos masculinos (en buena medida inventados y construidos culturalmente que llevamos en nosotros mismos como inagotables fuentes de excitación)" (1995: 96).

La pornificación de las imágenes extrapornográficas mencionadas por Alberto y Omar parecen prefigurar las representaciones de los cuerpos masculinos tal y como las elaborará la pornografía gay mainstream. 


\section{PORNOGRAFÍA GAY MAINSTREAM}

La pornografía gay mainstream es "una pequeña escuela", dice durante la entrevista Celio, otro informante. Su afirmación podría sintetizar la percepción de todos los entrevistados. Y como en toda escuela, para seguir con la metáfora, encontramos al "matadito" (el que interioriza sin dificultad las enseñanzas y las reproduce) y al rebelde (el que cuestiona las enseñanzas y propone saberes alternativos). Cualquiera que sea la actitud frente a la pornografía, ésta parece funcionar como un dispositivo iniciático, ${ }^{18}$ incluso prescriptivo, en el campo interaccional de las prácticas sexuales.

Guillermo cuenta, por ejemplo, que "en general la pornografía es muy dada a la penetración" $y$, en los encuentros casuales "si hay penetración hay éxito, si no, es un fracaso"; Lino confirma en los hechos esta afirmación, cuando cuenta que, antes de conocer a su actual pareja, para él no había sexo si no había penetración: "porque, ¿para qué quieres un encuentro si nada más te vas a ir a frotar los genitales? [...] El encuentro era puro sexo, pura penetración, el encuentro era coger y penetrar y eyacular y vámonos." Mauricio confiesa que, antes de tener su primera experiencia como pasivo, recurrió a películas porno para "imaginarme cómo me iba a preparar, cómo me iba a poner". Descubre también que "entre hombres podías coger $\mathrm{y}$ verte de frente". Bernardino descubre y práctica el beso negro (lamer el ano); Gilberto y Guillermo el

18 Siguiendo los apuntes teóricos de Giorgio Agamben, entendemos por dispositivo "todo aquello que tiene, de una manera u otra, la capacidad de capturar, orientar, determinar, interceptar, modelar, controlar y asegurar los gestos, las conductas, las opiniones y los discursos de los seres vivos" (2011: 257). fisting. Mauricio ha observado que algunos amantes casuales intentan reproducir escenas fuertemente codificadas o coreografiadas de las películas porno, como "nalguear", "escupir en el ano" o "golpear el pene contra el ano": "lo más chistoso", dice, "ha sido que te golpean con el pene en la cara o en el ano; obviamente viene de ahí, porque yo no le encuentro más función". ${ }^{19}$ Para algunos informantes (Javi, Omar), el 69 empieza a practicarse por influencia de los videos pornográficos.

La pornografía funciona también como reveladora de fantasías sexuales. A varios les gustaría participar en una orgía. Hugo tiene ganas de probar "el dos romano", es decir, ser penetrado por dos penes simultáneamente. Para la mayoría, las películas y videos pornográficos vistos en internet presentan una gama extensa de cuerpos, espacios y posiciones sexuales capaces de satisfacer sus fantasías: cuerpos masculinos, viriles y velludos, negros bien dotados y musculosamente marcados, güeros flacos, osos, gordos, chacales (aunque no existe una definición exclusiva del chacal, generalmente es percibido como proletario urbano, de bajos recursos económicos, con rasgos indígenas), lluvia dorada (orinar en el cuerpo del otro o ser orinado por el otro), beso negro, sexo oral y anal, fisting, tríos y orgías, calles, cárceles, parques, metro, baños, etcétera.

La tabla 2 (ver anexos) da cuenta de la relación de los entrevistados con la pornografía gay e indica los soportes utilizados, los elementos valorados o rechazados. También hace referencia

19 La tabla 2 ("Los entrevistados y su relación con la pornografía") hace un inventario detallado de los elementos valorados o descalificados en la pornografía por los entrevistados. 
al grado de importancia de la pornografía en las prácticas sexuales de los entrevistados. Los soportes utilizados de consumo son, en primer lugar, internet (12) ${ }^{20}$ en segundo, los DVD (8), en tercero, las revistas pornográficas (6), en cuarto y quinto lugar, los canales televisivos (4) y diferentes relatos o novelas (3). La producción audiovisual mexicana, unos 20 títulos como máximo, es desconocida, ignorada o rechazada por su "mala" calidad. Sólo un entrevistado expresa su gusto por videos amateur, de muy corta duración, filmados en el último vagón del metro. ${ }^{21}$ Se consume mayoritariamente videos extranjeros (estadounidenses y europeos). Aunque algunos entrevistados valoran la narratividad, es decir el hecho de que haya una "historia" en el guión (3), la mayoría prefiere la exhibición de escenas de sexo explícito.

Entre las prácticas mencionadas como excitantes destacan, aunque nunca de manera mayoritaria: la penetración (7), sexo en lugares públicos (4), sexo oral (4), prácticas sadomasoquistas (3), eyaculación visible (2), orgías (2), y luego siguen, mencionados una sola vez: la lluvia dorada, besos, caricias, fisting, bondage, nalgadas, bareback (sexo sin condón), beso negro.

No hay una preferencia ni especial ni dominante por un tipo racial de cuerpo, pero se menciona explícitamente a los negros (3), los chacales (2) y el tipo blanco europeo (3). Las partes del cuerpo que algunos entrevistados mencionan explícitamente son: el miembro (4), las nalgas

20 Los números entre paréntesis indican la cantidad de entrevistados que mencionan la categoría evocada.

21 El último vagón del metro, denominado por algunos gay del Distrito Federal "el puti-vagón”, es un lugar de ligue homosexual.
(2), torso velludo (2), piernas y pies (1). El tipo de cuerpo valorado directa o indirectamente por los entrevistados es el masculino no afeminado, cualquiera que sea su forma, talla o edad [gordos (3), osos (2), gente común y corriente (1), flacos (1), altos (1), hombres maduros (3), gente joven (3)]. Sólo dos entrevistados expresan su gusto por cuerpos que difieren de las codificaciones masculinas hegemónicas: uno menciona su gusto por cuerpos trans (mujeres y hombres trans) y otro su gusto por cuerpos andróginos.

Una de las preguntas se relacionaba con lo que los informantes descartaban de la pornografía por no corresponder con sus gustos. En un orden decreciente, aparecen los elementos siguientes: el fisting (4), prácticas sadomasoquistas (4), penetración (4), sexo oral (3), hombres gordos y rudos (3), violencia (3), introducción anal de objetos (2), preámbulos a la práctica sexual (2), coprofilia (2), caricias (1), eyaculación (1), sexo con trans (1), lluvia dorada (1), encuadres cerrados (1).

A la pregunta: ¿crees que la pornografía tuvo o tiene cierta importancia en el descubrimiento de tu sexualidad?, 11 entrevistados (de los 15) contestaron de manera afirmativa.

A la luz de las respuestas, se puede inferir que la pornografía cumple en los informantes las tres funciones siguientes:

Función excitatoria: para la práctica masturbatoria, evidentemente, pero algunos informantes también recurren a la pornografía para alcanzar cierto grado de excitación cuando van a practicar sexo con su pareja.

Función iniciática: descubrimiento de nuevas posiciones o prácticas sexuales (7) que tienen 
incidencia en los guiones interpersonales (beso negro, sexo oral, "hacerlo de frente", manera de comportarse como pasivo, etcétera). Guillermo cuenta que experimentó su primera masturbación repitiendo los gestos vistos en una película porno: "yo no entendía qué era la masturbación [...] entonces yo vi la película y repetí lo que vi, como por instinto llegué a esa primera masturbación.” En el caso de Bernardino, la pornografía le permitió descubrir "cómo tienen sexo los mexicanos". Criado en Estados Unidos, Bernardino, de origen mexicano, pensaba que el mexicano "es muy agresivo, muy macho o que coge a la mujer como animal". Antes de concretar un encuentro sexual con un mexicano, quiso ver en DVD cómo "eran en la cama".

Función mimética: esencialmente en los encuentros casuales. Algunos informantes cuentan cómo en algunas situaciones sexuales la persona con quien están intenta reproducir prácticas vistas en los videos (penetración como requisito para valorar el éxito del encuentro, escupir en el ano, golpear el ano o la cara con el pene, emplear expresiones como fuck me, etcétera).

El análisis detenido de las entrevistas me llevó a las siguientes observaciones:

a) El consumo de pornografía ocupa un lugar importante en la vida de los informantes. La pornografía, cuya producción se ha disparado con la generalización del acceso domiciliario a internet, ha dejado de ser marginal y se ha convertido en un género popular por excelencia, como señalan Cervulle y Rees-Roberts (2010: 55).22

22 Basándose en los estudios de Feona Attwood ("Reading b) A pesar de ser considerada como "aburrida" y "repetitiva" por algunos, ningún informante afirma haber dejado de consumir pornografía. Una de las razones, no dicha explícitamente, se debería al hecho de que la industria pornográfica presenta una multitud de hombres excitantes, deseables y desechables; una multitud de situaciones sexuales. La pornografía ofrece, por consiguiente, la ilusión de poder elegir con frecuencia, sin limitación y en un tiempo muy breve, posiciones, cuerpos y orgasmos, al tiempo que posibilita la libre disposición de un amplísimo harem, siempre disponible, siempre consintiente, siempre complaciente. Al contrario de lo que sucede en situaciones de contacto real, particularmente en los lugares de ligue, el esfuerzo para llegar al orgasmo con la pornografía es mínimo: ningún desplazamiento espacial, ninguna espera, ninguna estrategia de seducción, ningún rechazo y ningún riesgo. Más aún, las opciones técnicas del lector de video permiten escoger la escena, adelantar rápidamente hasta encontrar el cuerpo, la posición y la práctica deseados, sin ninguna resistencia del virtual acompañante.

c) La imagen pornográfica difunde modelos de guiones interpersonales que el sujeto (homo) erótico ensaya en la interacción social. Es la base de una matriz hegemónica, homonormada, en la que los homosexuales, preocupados por lo que creen que sus amantes casuales esperan de ellos,

Porno: The Paradigm Shift in Pornography Research", Sexualities, vol. 5, núm. 1. Londres, Thousand Oaks, Sage Publicactions, 2002, pp. 91-105) y de Linda Williams (2004), Cervulle y Rees-Roberts señalan que la producción pornográfica es masivamente consumida por todos los sectores de la población, y constituye, por consiguiente, un género popular. 
van a encontrar una fuente de inspiración. Fuera de dicha matriz, toda conducta sexual "alternativa" puede ser descalificada en la interacción (homo) social. Por eso, parece prevalecer en los encuentros casuales los guiones interpersonales codificados por las producciones pornográficas mainstream, en las que se privilegia el sexo oral, el beso negro y la penetración anal.

d) La pornografía mainstream presenta mayoritariamente la idealización (imagen y modelo) del cuerpo gay masculino, cuyos rasgos constitutivos son similares a la idealización del cuerpo masculino heterocentrado (viril, súper dotado, musculoso). Dicha idealización, que se elabora excluyendo de las representaciones todo afeminamiento, parece ser compartida por la mayoría de los entrevistados. Si bien los cuerpos masculinos difieren en cuanto a talla, masa, pilosidad, edad o color de piel, lo que permanece como constante en las representaciones pornográficas gay es la codificación hegemónica de la masculinidad. Queda excluida de dichas representaciones toda marca que podría señalar una transgresión (hombresfemeninos-homosexuales, por ejemplo) de los códigos del orden del género. En este sentido, en la codificación pornográfica del cuerpo gay, se puede percibir cierta carga homofóbica que la flexibilidad lingüística nos permitiría calificar de "locafóbica". La imagen de la "loca" o del homosexual afeminado no constituye un tropo pornográfico excitante para la casi totalidad de los entrevistados. Sólo Javi expresa su gusto por cuerpos trans en su consumo de pornografía.

\section{CONSIDERACIONES FINALES}

Uno de los poderes de la pornografía gay mainstream - rasgo que comparte con la pornografía heterosexual - radica en su capacidad de construir una potente ilusión referencial. Dicho de otro modo, la pornografía se constituye como régimen discursivo cuya pretensión es dar a ver -y por consiguiente, a conocer-, a través de la exhibición hiperrealista de cuerpos erotizados, diferentes combinaciones sexuales posibles y diferentes maneras de practicarlas. La ilusión referencial, trampa seductora en la que caen (caemos) gustosa y fácilmente todos los consumidores de pornografía, es la que contribuye a provocar la excitación masturbatoria. Es también la que acompaña fragmentaria y parcialmente nuestra construcción en tanto sujetos (homo)eróticos.

Más allá de su función excitatoria, la puesta en escena de cuerpos masculinos que gozan de manera placentera entre ellos, sin ninguna inhibición, en lugares tan diversos como domicilios, calles, cárceles, parques, talleres de automóviles, baños públicos, etc., proporciona un referente positivo. Dicho referente refuerza indirectamente la conformación de subjetividades (homo)eróticas y la afirmación de una identidad homosexual. La pornografía gay cobra de facto importancia en los procesos iniciáticos, $\mathrm{y}$, por ende, en los procesos de socialización de los jóvenes homosexuales, como lo revela la mayoría de las entrevistas realizadas. La repetición ad infinitum de actos (homo)sexuales centrados en determinadas partes del cuerpo (boca, pene, ano), las representaciones masivas de cuerpos masculinos, codificados según las normas sociales en vigor, tienden a generar — aunque sería más exacto decir "revelar" - un modelo homonormado 
—un "deber ser" y un "deber hacer" homosexualdotado de capital (homo)social: esencialmente un hombre masculino a quien le gusta el sexo oral, penetrar $\mathrm{y} / \mathrm{o}$ ser penetrado, $\mathrm{y}$ cuya fuente de placer está, en consecuencia, centrada en el pene o en el ano. Si bien la mayoría de los entrevistados se encuentra en esta línea, algunos perciben y expresan su inadecuación con este modelo. Alberto precisa en la entrevista que es un "homosexual muy raro" porque no le gusta "el miembro" y porque, según él, la fuente del placer está en la piel, no en los genitales. Para él la pornografía gay mainstream es vista como una escenificación distópica de la sexualidad. Javi, consciente de su "estética andrógina", está "trabajando con la identidad trans" y le es muy difícil definirse. Le interesa "permanecer en el margen de los géneros" y, por consiguiente, salir de los modelos hegemónicos de la homosexualidad acarreados por la producción pornográfica.

Ahora bien, la pornografía, por paradójico que pueda parecer, no inventa las fantasías (homo) sexuales, las pornifica. Su capacidad creativa se limita, debido a su doble imperativo referencialhiperrealista y económico, a materializar, poniendo en imágenes seductoras, aquellos guiones sexuales latentes o patentes en una mayoría de sujetos (homo)eróticos. Sólo ofrece algunos tipos de cuerpos y algunas prácticas sexuales que el sujeto homo(erótico) ya tiene inscritos consciente o inconscientemente en sus guiones intrapsíquicos, previamente gestados a través de un complejo proceso psico-socio-histórico. Según Naief Yehya, "la pornografía es tan sólo parte de la experiencia, un elemento que a menudo debe ser completado y que es la materia prima para la fantasía" (2004:
251). Quizá cabría matizar y ver en la pornografía menos "la materia prima para la fantasía" que la pornificación de una materia prima intrapsíquica. $\mathrm{Su}$ éxito se debería a su capacidad de extraer esa materia prima, convertirla en producto elaborado, en bien de consumo deseable, en máquina masturbatoria y en posible guión para la interacción homosexual. ৯o 
ANEXOS

Tabla 1.

Composición del grupo de informantes

\begin{tabular}{|c|c|c|c|c|c|}
\hline $\begin{array}{l}\text { NOMBRE } \\
\left(\text { FICTICIO) }{ }^{1}\right.\end{array}$ & EDAD & PROFESIÓN & $\begin{array}{l}\text { ¿RELACIÓN } \\
\text { AMOROSA? }\end{array}$ & $\begin{array}{l}\text { RESIDENCIA } \\
\text { ACTUAL }\end{array}$ & $\begin{array}{l}\text { ¿CÓMO SE } \\
\text { AUTODEFINEN?² }\end{array}$ \\
\hline Javi & 24 & $\begin{array}{l}\text { Estudiante de } \\
\text { maestría en artes } \\
\text { visuales }\end{array}$ & $\begin{array}{l}\text { No tiene relación de } \\
\text { pareja }^{3}\end{array}$ & D.F. (Portales) & $\begin{array}{l}\text { Ahora: "trans, queer, } \\
\text { ambiguo" (masculino y } \\
\text { femenino). "Bixexual a } \\
\text { partir de los } 13 \text { años, gay } \\
\text { a partir de los } 18 \text { años" }\end{array}$ \\
\hline Hugo & 25 & Estilista & $\begin{array}{l}\text { En relación: "sale } \\
\text { con alguien", } \\
\text { domicilio no } \\
\text { compartido }\end{array}$ & D.F. (Obrero Mundial) & $\begin{array}{l}\text { "Gay", "hombre", } \\
\text { "masculino: no tanto, } \\
\text { pero sí" }\end{array}$ \\
\hline Bernardino & 25 & $\begin{array}{l}\text { Estudiante de } \\
\text { maestría }\end{array}$ & $\begin{array}{l}\text { En pareja desde } \\
\text { hace unos } \\
\text { meses, domicilio } \\
\text { compartido }\end{array}$ & $\begin{array}{l}\text { Estados Unidos / D.F. } \\
\text { (Roma) }\end{array}$ & $\begin{array}{l}\text { "No me defino por nada, } \\
\text { nada más me dejo llevar } \\
\text { por lo que mi cuerpo } \\
\text { pide. Si me pide mujer } \\
\text { es mujer, pero nunca he } \\
\text { estado con una mujer" }\end{array}$ \\
\hline Lino & 27 & $\begin{array}{l}\text { Ejecutivo en } \\
\text { banco }\end{array}$ & $\begin{array}{l}\text { En pareja desde } \\
\text { hace dos años, } \\
\text { domicilio } \\
\text { compartido }\end{array}$ & D.F. (Nativitas) & "Gay. Hombre gay" \\
\hline José & 27 & $\begin{array}{l}\text { Licenciado } \\
\text { en derecho; } \\
\text { estudiante de } \\
\text { licenciatura en } \\
\text { filosofía y letras }\end{array}$ & $\begin{array}{l}\text { No tiene relación de } \\
\text { pareja }\end{array}$ & D.F. & $\begin{array}{l}\text { "Hombre". "Puto". "No } \\
\text { me gustan las palabras } \\
\text { 'gay' ni 'homosexual"” }\end{array}$ \\
\hline Mauricio & 28 & $\begin{array}{l}\text { Estudiante de } \\
\text { doctorado en } \\
\text { historia }\end{array}$ & $\begin{array}{l}\text { En relación de } \\
\text { pareja, domicilio no } \\
\text { compartido }\end{array}$ & D.F. / San Luis Potosí & "Gay. Hombre gay" \\
\hline Celio & 31 & Médico; actor & $\begin{array}{l}\text { No tiene relación de } \\
\text { pareja }\end{array}$ & Xalapa & $\begin{array}{l}\text { "Sexo: masculino; } \\
\text { orientación sexual: } \\
\text { homosexual; género: } \\
\text { hombre" }\end{array}$ \\
\hline Guillermo & 34 & Actor & $\begin{array}{l}\text { En relación de } \\
\text { pareja, domicilio no } \\
\text { compartido }\end{array}$ & D.F. (Zona Rosa) & $\begin{array}{l}\text { "Hombre en el género. } \\
\text { Bisexual hasta los } 18, \\
\text { gay a partir de los } 18 "\end{array}$ \\
\hline Víctor & 38 & $\begin{array}{l}\text { Profesor en } \\
\text { primaria }\end{array}$ & $\begin{array}{l}\text { En pareja desde } \\
\text { hace seis años, } \\
\text { domicilio } \\
\text { compartido }\end{array}$ & Xochimilco & $\begin{array}{l}\text { "Hombre homosexual", } \\
\text { "gay" }\end{array}$ \\
\hline Amancio & 44 & $\begin{array}{l}\text { Dramaturgo; } \\
\text { estudiante de } \\
\text { doctorado en } \\
\text { teatro }\end{array}$ & $\begin{array}{l}\text { En pareja desde } \\
\text { hace seis años, } \\
\text { domicilio } \\
\text { compartido }\end{array}$ & D.F. (Condesa) & "Hombre homosexual" \\
\hline Gilberto & 47 & Fotógrafo & $\begin{array}{l}\text { En pareja } \\
\text { desde hace } 25 \\
\text { años, domicilio } \\
\text { compartido }\end{array}$ & D.F. (Condesa) & $\begin{array}{l}\text { "Homosexual. Siempre } \\
\text { con hombres. Jamás con } \\
\text { una mujer" }\end{array}$ \\
\hline
\end{tabular}




\begin{tabular}{|l|l|l|l|l|l|}
\hline Diego & 56 & Jubilado (Pemex) & $\begin{array}{l}\text { En pareja } \\
\text { desde hace 25 } \\
\text { años, domicilio } \\
\text { compartido }\end{array}$ & D.F. (Condesa) & $\begin{array}{l}\text { "Gay, homosexual". } \\
\text { "Hombre" }\end{array}$ \\
\hline Maximiliano & 65 & $\begin{array}{l}\text { Arquitecto; } \\
\text { diseñador }\end{array}$ & $\begin{array}{l}\text { No tiene relación de } \\
\text { pareja }\end{array}$ & $\begin{array}{l}\text { Cartagena (Colombia) / } \\
\text { D.F. }\end{array}$ & $\begin{array}{l}\text { Hoy: "homosexual”. } \\
\text { Antes: "bisexual” }\end{array}$ \\
\hline Omar & 69 & $\begin{array}{l}\text { Jubilado } \\
\text { (médico) }\end{array}$ & $\begin{array}{l}\text { En pareja desde } \\
\text { hace seis años, } \\
\text { domicilio } \\
\text { compartido }\end{array}$ & D.F. (Condesa) & "Homosexual 100\%" \\
\hline Alberto & 76 & $\begin{array}{l}\text { Jubilado } \\
\text { (ejecutivo de } \\
\text { banco) }\end{array}$ & $\begin{array}{l}\text { No tiene relación de } \\
\text { pareja }\end{array}$ & D.F. (Mixcoac) & $\begin{array}{l}\text { "Homosexual, pero un } \\
\text { homosexual muy raro" } \\
\text { "Hombre homosexual" }\end{array}$ \\
\hline
\end{tabular}

1 Todos los nombres son ficticios excepto el de Bernardino que no se cambió a petición expresa del informante.

2 En esta columna restituyo entre comillas las palabras con las que se autodefinen los informantes. Es la respuesta a la pregunta: “¿cómo te defines desde un punto de vista de género, sexo, orientación sexual?

3 Por pareja se entiende relación sexual o amorosa estable y prioritaria con una persona. Es también el término que usan los informantes para mencionar a la persona con quien están saliendo o viviendo de manera privilegiada o exclusiva. 
Tabla 2.

Los entrevistados y su relación con la pornografía

\begin{tabular}{|c|c|c|c|c|c|}
\hline $\begin{array}{l}\text { NOMBRE } \\
\text { EDAD }\end{array}$ & $\begin{array}{l}\text { SOPORTE } \\
\text { PORNO }\end{array}$ & $\begin{array}{l}\text { RECURRE } \\
\text { AL PORNO } \\
\text { DESDE... }\end{array}$ & $\begin{array}{l}\text { EN EL PORNO LE } \\
\text { GUSTA(N)... }\end{array}$ & $\begin{array}{l}\text { NO LE } \\
\text { GUSTA(N)... }\end{array}$ & $\begin{array}{l}\text { IMPORTANCIA DE LA } \\
\text { PORNOGRAFÍA EN EL } \\
\text { DESCUBRIMIENTO DE } \\
\text { LA SEXUALIDAD / PAPEL } \\
\text { DEL PORNO EN LAS } \\
\text { PRÁCTICAS SEXUALES } \\
\end{array}$ \\
\hline $\begin{array}{l}\text { Amancio, } \\
44 \text { años }\end{array}$ & $\begin{array}{l}\text {-Películas porno } \\
\text { heterosexuales } \\
\text { en } 8 \mathrm{~mm} \text { (a los } \\
12 \text { años) } \\
\text {-Revistas } \\
\text {-Internet }\end{array}$ & $\begin{array}{l}\text { Edad de } 12 \\
\text { años, primero, } \\
\text { y luego ya a } \\
\text { los } 40 \text { años }\end{array}$ & $\begin{array}{l}\text {-Penetración } \\
\text {-Que se vean los } \\
\text { cuerpos ("me gusta ver } \\
\text { la edad de la persona") } \\
\text {-La gente común y } \\
\text { corriente } \\
\text {-El incesto (videos } \\
\text { en los que el hijo } \\
\text { está espiando al papá } \\
\text { que está durmiendo } \\
\text { desnudo en la cama o } \\
\text { bañándose) }\end{array}$ & $\begin{array}{l}\text {-Sexo oral } \\
\text {-Hombres } \\
\text { afeminados }\end{array}$ & $\begin{array}{l}\text {-Las primeras masturbaciones } \\
\text { con los primos se hacen viendo } \\
\text { revistas porno } \\
\text {-A Amancio le gustan "los } \\
\text { viejos", de } 60 \text { años para arriba. } \\
\text { Desde hace poco tiempo hay } \\
\text { videos con personas mayores } \\
\text {-No le aporta nada respecto a } \\
\text { prácticas sexuales }\end{array}$ \\
\hline $\begin{array}{l}\text { Bernardino, } \\
25 \text { años }\end{array}$ & $\begin{array}{l}\text {-DVD } \\
\text {-Internet }\end{array}$ & $\begin{array}{l}\text { Edad de } 20 \\
\text { años }\end{array}$ & $\begin{array}{l}\text {-Que haya una historia } \\
\text {-El desnudarse de los } \\
\text { actores } \\
\text {-Penetración, sexo anal } \\
\text { ("tres escenas: la } \\
\text { primera es el coqueteo, } \\
\text { la segunda el beso } \\
\text { negro y ya después } \\
\text { la penetración y } \\
\text { masturbación y ya" }\end{array}$ & $\begin{array}{l}\text {-El fisting } \\
\text {-Lluvia dorada } \\
\text {-Introducción de } \\
\text { objetos } \\
\text {-El } \\
\text { sadomasoquismo } \\
\text {-“Chicos muy } \\
\text { barbones, personas } \\
\text { que pudieran ser } \\
\text { mis papás" } \\
\text {-Chicos gordos, } \\
\text { rudos }\end{array}$ & $\begin{array}{l}\text {-Sí (Bernardino se crió en } \\
\text { Estados Unidos y en las } \\
\text { películas porno mexicanas } \\
\text { descubre cómo tienen sexo } \\
\text { los mexicanos. Para él, el } \\
\text { mexicano era "muy agresivo, } \\
\text { muy macho o que cogen a la } \\
\text { mujer como animal"). } \\
\text {-Descubre y practica el beso } \\
\text { negro. } \\
\text {-Descubre y practica } \\
\text { posiciones vistas en la } \\
\text { pornografía como hacerlo de } \\
\text { frente } \\
\text {-Le gustaría hacer un trio }\end{array}$ \\
\hline $\begin{array}{l}\text { Celio, } \\
31 \text { años }\end{array}$ & $\begin{array}{l}\text {-DVD } \\
\text {-Internet } \\
\text {-Cuentos } \\
\text { eróticos }\end{array}$ & No respondió & $\begin{array}{l}\text {-Las piernas y los pies } \\
\text {-Hombres velludos, los } \\
\text { osos, los leathers } \\
\text {-Sexo en lugares } \\
\text { públicos (baños, cines, } \\
\text { metro, transporte } \\
\text { público) } \\
\text {-Europeos }\end{array}$ & No respondió & $\begin{array}{l}\text {-Sí } \\
\text {-"Es como una pequeña } \\
\text { escuela" }\end{array}$ \\
\hline $\begin{array}{l}\text { Diego, } \\
56 \text { años }\end{array}$ & $\begin{array}{l}\text {-Revistas } \\
\text {-Películas en } 8 \\
\text { mm } \\
\text {-DVD } \\
\text {-Canales } \\
\text { televisivos } \\
\text {-Internet }\end{array}$ & $\begin{array}{l}\text {-Edad de } \\
25 / 26 \text { años, } \\
\text { primero con } \\
\text { revistas }\end{array}$ & $\begin{array}{l}\text {-Que haya una historia } \\
\text {-Filmar a los chicos a } \\
\text { los que contrata para } \\
\text { tener sexo } \\
\text {-Caricias, besos entre } \\
\text { los actores } \\
\text {-Chicos de piel } \\
\text { morena, tipo mexicano }\end{array}$ & $\begin{array}{l}\text {-Los gordos, los } \\
\text { güeros } \\
\text {-Sadomasoquismo, } \\
\text { golpes, coprofilia }\end{array}$ & $\begin{array}{l}\text {-Sí } \\
\text {-Descubrimiento de nuevas } \\
\text { posiciones } \\
\text {-Influye en las prácticas } \\
\text { sexuales con su pareja (hacen } \\
\text { cosas vistas en películas } \\
\text { porno) }\end{array}$ \\
\hline
\end{tabular}




\begin{tabular}{|c|c|c|c|c|c|}
\hline $\begin{array}{l}\text { Gilberto, } \\
47 \text { años }\end{array}$ & $\begin{array}{l}\text {-VHS } \\
\text {-Revistas } \\
\text {-Canales } \\
\text { televisivos } \\
\text {-DVD }\end{array}$ & $\begin{array}{l}\text {-Edad de } 16 \\
\text { años, cuando } \\
\text { iba a casa de } \\
\text { algún hombre } \\
\text { y él ponía } \\
\text { alguna película }\end{array}$ & $\begin{array}{l}\text {-Más las películas } \\
\text { porno heterosexual } \\
\text { que gay } \\
\text {-Cuando le bajan } \\
\text { el calzón y se ve } \\
\text { el miembro, y la } \\
\text { eyaculación } \\
\text {-Ver Fisting } \\
\text {-Hombres flacos y } \\
\text { pitudos }\end{array}$ & $\begin{array}{l}\text {-Ver una película } \\
\text { más de una vez } \\
\text {-Escenas violentas } \\
\text { (golpes) } \\
\text {-Coprofilia }\end{array}$ & $\begin{array}{l}\text {-Sí } \\
\text {-Practica el fisting pero no con } \\
\text { su pareja } \\
\text {-Una vez a la semana (fin } \\
\text { de semana) pasa todo el día } \\
\text { viendo pornografía } \\
\text {-Generalmente ese día, } \\
\text { contrata con su pareja y por } \\
\text { internet a chicos prostitutos } \\
\text {-La pornografía lo mantiene } \\
\text { "activo sexualmente" }\end{array}$ \\
\hline $\begin{array}{l}\text { Guillermo, } \\
34 \text { años }\end{array}$ & $\begin{array}{l}\text {-VHS, primero } \\
\text {-DVD } \\
\text {-Canales } \\
\text { televisivos } \\
\text {-Novelas gay }\end{array}$ & $\begin{array}{l}\text { Descubre } \\
\text { película } \\
\text { porno a los } 12 \\
\text { años con la } \\
\text { parodia porno } \\
\text { de Cyrano } \\
\text { de Bergerac } \\
\text { (primera } \\
\text { masturbación) }\end{array}$ & $\begin{array}{l}\text {-Orgías } \\
\text {-Toma completa del } \\
\text { cuerpo }\end{array}$ & $\begin{array}{l}\text {-El rollo leather } \\
\text {-Penetración ("me } \\
\text { puede aburrir") } \\
\text {-Encuadres } \\
\text { cerrados }\end{array}$ & $\begin{array}{l}\text {-Sí } \\
\text {-"Ha sido cosa de ir viendo } \\
\text { e ir copiando", "creo que la } \\
\text { primera vez que lo que yo } \\
\text { veía, si lo iba a hacer o no, } \\
\text { era a través de la pornografía, } \\
\text { si me generaba gusto ya lo } \\
\text { buscaba yo" } \\
\text {-"El fisting sí lo he } \\
\text { experimentado, fue un } \\
\text { descubrimiento, una excitación } \\
\text { muy grande" (Guillermo se lo } \\
\text { practicó a un amante casual) } \\
\text {-"Muchas dudas me las ha } \\
\text { despejado la pornografía" } \\
\text {-Influencia de la pornografía } \\
\text { gay en los encuentros casuales: } \\
\text { "en general la pornografía gay } \\
\text { es muy dada a la penetración } \\
\text { y creo que pasa mucho en los } \\
\text { encuentros casuales, si hay } \\
\text { penetración hay éxito y si no, } \\
\text { es un fracaso" }\end{array}$ \\
\hline $\begin{array}{l}\text { Hugo, } \\
25 \text { años }\end{array}$ & $\begin{array}{l}\text {-Revistas } \\
\text { heterosexuales } \\
\text { (en un principio) } \\
\text {-Revistas } \\
\text {-DVD } \\
\text {-Internet (videos } \\
\text { y chat) }\end{array}$ & $\begin{array}{l}\text {-Edad de } 8 \\
\text { años }\end{array}$ & $\begin{array}{l}\text {-Hombres maduros, } \\
\text { llenitos } \\
\text {-Tríos o con mucha } \\
\text { gente, "salvajes" } \\
\text {-Escenas tipo asaltos, } \\
\text { policías que descubren } \\
\text { a gente teniendo sexo } \\
\text { en un baño. } \\
\text {-Cárcel, calle } \\
\text {-Muchachos } \\
\text { güeritos, "cabello } \\
\text { chinito, marcadones, } \\
\text { grandotes" } \\
\text {-Gente de piel clara } \\
\text {-Nalgadas } \\
\text {-Escenas } \\
\text { sadomasoquistas } \\
\text {-Bareback (sexo no } \\
\text { protegido) }\end{array}$ & $\begin{array}{l}\text {-Sexo oral ("me } \\
\text { aburre") }\end{array}$ & $\begin{array}{l}\text {-Sí } \\
\text {-Influye en la manera de hacer } \\
\text { el sexo oral, o cómo tocar } \\
\text {-Tiene ganas de probar el "dos } \\
\text { romano" (penetración por dos } \\
\text { hombres al mismo tiempo) }\end{array}$ \\
\hline
\end{tabular}




\begin{tabular}{|c|c|c|c|c|c|}
\hline $\begin{array}{l}\text { Javi, } \\
24 \text { años }\end{array}$ & $\begin{array}{l}\text {-Canal televisivo } \\
\text {-Internet }\end{array}$ & $\begin{array}{l}\text { Edad de } 16 \\
\text { años }\end{array}$ & $\begin{array}{l}\text {-Negros } \\
\text {-personas gordas } \\
\text {-Personas trans } \\
\text {-Que haya una historia } \\
\text {-Sexo oral, oralidad } \\
\text { (lamer el cuerpo, partes } \\
\text { del cuerpo) } \\
\text {-Lluvia dorada, } \\
\text { bondage }\end{array}$ & -Fisting & $\begin{array}{l}\text {-No } \\
\text {-Considera que la pornografía } \\
\text { sí marca comportamientos (“el } \\
\text { porno ha dado un recetario a } \\
\text { quien lo mira para aplicarlo } \\
\text { en su práctica, por ejemplo, es } \\
\text { muy común el 69") } \\
\text {-Ha estado con gente que le } \\
\text { propone ver porno y hacer lo } \\
\text { que pasa en la película (escena } \\
\text { del doctor y el paciente, } \\
\text { realizadas) }\end{array}$ \\
\hline $\begin{array}{l}\text { Lino, } \\
27 \text { años }\end{array}$ & $\begin{array}{l}\text {-BETA y VHS } \\
\text { (primero) } \\
\text {-Internet } \\
\text {-Novelas gay }\end{array}$ & $\begin{array}{l}\text {-Descubre } \\
\text { pornografía } \\
\text { heterosexual a } \\
\text { los } 13 \text { años }\end{array}$ & $\begin{array}{l}\text {-Penetración } \\
\text {-Negros ("verga, } \\
\text { pectorales, brazos } \\
\text { marcados") } \\
\text {-Hombres maduros } \\
\text { trajeados } \\
\text {-Sexo oral y anal } \\
\text {-Eyaculación fuera del } \\
\text { ano }\end{array}$ & $\begin{array}{l}\text {-Caricias, } \\
\text { preámbulo } \\
\text {-Sexo con trans } \\
\text {-"Dos chicos rudos } \\
\text { cogiendo" }\end{array}$ & $\begin{array}{l}\text {-Sí ("he descubierto } \\
\text { posiciones") }\end{array}$ \\
\hline $\begin{array}{l}\text { Mauricio, } \\
28 \text { años }\end{array}$ & $\begin{array}{l}\text {-Películas de arte } \\
\text { como El último } \\
\text { emperador } \\
\text {-Relatos eróticos } \\
\text {-Revistas } \\
\text {-Internet }\end{array}$ & $\begin{array}{l}\text {-Edad de } \\
10 \text { años y } \\
\text { luego en la } \\
\text { licenciatura }\end{array}$ & $\begin{array}{l}\text {-Osos } \\
\text {-Hombres como de } \\
\text { 40, muy masculinos y } \\
\text { velludos } \\
\text {-Llenitos, nalgas } \\
\text { velludas, bien dotados } \\
\text {-Tipo árabes } \\
\text {-"Me gusta cuando } \\
\text { empieza y tienen la } \\
\text { ropa puesta y se la } \\
\text { van quitando, y justo } \\
\text { se quitan el calzón y } \\
\text { sacan la verga y uno se } \\
\text { sorprende" } \\
\text {-"Cuando se vienen y } \\
\text { si se vienen } \\
\text { mucho, me encanta" } \\
\text {-Porno amateur (en el } \\
\text { metro) } \\
\text {-Cámaras escondidas } \\
\text { en los vestidores }\end{array}$ & $\begin{array}{l}\text {-Penetración } \\
\text {-Fisting } \\
\text {-Introducción } \\
\text { de objeto (como } \\
\text { botella de cerveza, } \\
\text { por ejemplo) }\end{array}$ & $\begin{array}{l}\text {-Sí (“tenía muy poca } \\
\text { imaginación”) } \\
\text {-“Cuando he estado en pasivo, } \\
\text { sí recurrí alguna vez a una } \\
\text { película porno como para } \\
\text { imaginarme cómo me iba } \\
\text { a preparar, cómo me iba a } \\
\text { poner, no tenía mucha idea, } \\
\text { posiciones también, incluso } \\
\text { descubrí que entre hombres } \\
\text { podías coger y verte de frente } \\
\text { [...] me resultó útil, como un } \\
\text { manual de Kamasutra" } \\
\text {-Influencia del porno en } \\
\text { parejas casuales (golpear el } \\
\text { pene sobre el ano, decir "fuck, } \\
\text { fuck”) }\end{array}$ \\
\hline $\begin{array}{l}\text { Maximiliano, } \\
65 \text { años }\end{array}$ & -Internet & $\begin{array}{l}\text {-Edad de } 50 \\
\text { años más o } \\
\text { menos }\end{array}$ & $\begin{array}{l}\text {-El preámbulo } \\
\text {-Escenas de sexo oral } \\
\text { o anal } \\
\text {-Negros } \\
\text {-Chicanos } \\
\text {-Chacales }\end{array}$ & -Penetración & $\begin{array}{l}\text {-Quizá de manera inconsciente } \\
\text {-Algunos encuentros } \\
\text { reproducen escenas porno }\end{array}$ \\
\hline $\begin{array}{l}\text { Alberto, } \\
76 \text { años }\end{array}$ & $\begin{array}{l}\text {-Películas en } \\
\text { episodios tipo } \\
\text { Flash Gordon } \\
\text {-Novelas del } \\
\text { Oeste } \\
\text {-Revistas de } \\
\text { sadomasoquismo } \\
\text {-Internet }\end{array}$ & $\begin{array}{l}\text {-Desde los } 6 / 7 \\
\text { años }\end{array}$ & $\begin{array}{l}\text {-Escenas de tortura, } \\
\text { castigo } \\
\text {-Gente joven (entre } 18 \\
\text { y } 25 \text { años) } \\
\text {-Muchachos blancos }\end{array}$ & $\begin{array}{l}\text {-Pornografía } \\
\text { clásica gay } \\
\text { (penetración, } \\
\text { eyaculación, sexo } \\
\text { oral, etcétera) }\end{array}$ & $\begin{array}{l}\text {-No realmente } \\
\text {-La pornografía carece de } \\
\text { imaginación }\end{array}$ \\
\hline
\end{tabular}




\begin{tabular}{|c|c|c|c|c|c|}
\hline $\begin{array}{l}\text { Omar, } \\
69 \text { años }\end{array}$ & $\begin{array}{l}\text {-Películas en el } \\
\text { cine (primero) } \\
\text {-DVD }\end{array}$ & $\begin{array}{l}\text {-1969, cuando } \\
\text { se estrenaron } \\
\text { películas } \\
\text { porno gay }\end{array}$ & $\begin{array}{l}\text {-"Una gran verga } \\
\text { penetrando" } \\
\text {-Hombres velludos de } \\
\text { facciones masculinas, } \\
\text { pero también } \\
\text { jovencitos hermosos, } \\
\text { de piel de seda, con } \\
\text { unas nalgas hermosas" }\end{array}$ & $\begin{array}{l}\text {-Sadomasoquismo } \\
\text {-Comportamiento } \\
\text { violentos } \\
\text {-Fisting }\end{array}$ & $\begin{array}{l}\text {-Sí ("en mis relaciones } \\
\text { anteriores, la pornografía } \\
\text { sirvió para excitarnos y para } \\
\text { tener una mejor excitación en } \\
\text { el momento de la sexualidad" } \\
\text {-"Veía películas con mis } \\
\text { compañeros y eso ayudaba" } \\
\text {-"Empecé a hablar del } 69 \\
\text { [posición sexual] en los } 70 \text { en } \\
\text { donde la pornografía ya estaba } \\
\text { muy desarrollada" } \\
\text {-"Creo que la pornografía lleva } \\
\text { una función social" }\end{array}$ \\
\hline $\begin{array}{l}\text { Víctor, } \\
38 \text { años }\end{array}$ & $\begin{array}{l}\text {-Revistas } \\
\text {-VHS, BETA } \\
\text {-DVD } \\
\text {-Relatos } \\
\text {-Internet }\end{array}$ & $\begin{array}{l}\text {-Primer } \\
\text { contacto con } \\
\text { revista porno } \\
\text { a los } 8 \text { y } 12 \\
\text { años. Luego a } \\
\text { los } 17 / 18 \text { años }\end{array}$ & $\begin{array}{l}\text {-Leather } \\
\text {-Chacales } \\
\text {-Baños y metro } \\
\text {-Penetración, sexo oral } \\
\text { y anal } \\
\text {-Sexo en la calle, en } \\
\text { el carro, en lugares } \\
\text { oscuros }\end{array}$ & -Preámbulo & $\begin{array}{l}\text {-Sí } \\
\text {-Ve películas para excitarse } \\
\text { con su pareja } \\
\text {-Le gustaría participar en una } \\
\text { orgía }\end{array}$ \\
\hline $\begin{array}{l}\text { José, } \\
27 \text { años }\end{array}$ & $\begin{array}{l}\text {-Esencialmente } \\
\text { relatos en } \\
\text { revistas porno } \\
\text { (Atractivo, } \\
\text { Activo, por } \\
\text { ejemplo) } \\
\text {-Videos cortos } \\
\text { de sexo explícito }\end{array}$ & $\begin{array}{l}\text {-Desde la edad } \\
\text { de } 18 \text { años }\end{array}$ & $\begin{array}{l}\text {-"Hombres altos, } \\
\text { activos y dominantes" } \\
\text {-El "miembro viril", } \\
\text { "grueso" } \\
\text {-Escenas sado- } \\
\text { masoquistas }\end{array}$ & -Menores de edad & $\begin{array}{l}\text {-No } \\
\text {-La pornografía tiene más } \\
\text { influencia en heterosexuales } \\
\text { o bisexuales con los que tiene } \\
\text { sexo. Ellos, a veces, le piden } \\
\text { que adopte la postura vista } \\
\text { en las películas porno; le } \\
\text { dicen: "haz esto como el de la } \\
\text { película" } \\
\text { "La pornografía limita la } \\
\text { imaginación, repite patrones", }\end{array}$ \\
\hline
\end{tabular}




\section{BIBLIOGRAFÍA}

Agamben, Giorgio (2011), “QQué es un dispositivo?”, en Sociológica, año 26, núm. 73, mayo-agosto 2011, pp. 249-264.

Bersani, Leo (1995 [1988]), “¿Es el recto una tumba?”, en Ricardo Llamas (comp.), Construyendo sidentidades. Estudios desde el corazón de una pandemia. Madrid, Siglo XXI, pp. 79-115.

Bersani, Leo (1998), “Trahisons gaies”, en Didier Eribon (coord.), Les études gay et lesbiennes, Colloque du Centre Georges Pompidou, 23 et 27 juin 1997. Paris, Editions du Centre Pompidou, pp. 65-72.

Butler, Judith (2005), "Changer de sujet : la resignification radicale”, entrevista realizada por Gary A. Olson y Lynn Worsham, en Humain, inhumain, le travail critique des normes. Paris, Editions Amsterdam, pp. 93-145.

Butler, Judith (2006), Trouble dans le genre, pour un féminisme de la subversion. Paris, Editions La Découverte.

Cervulle, Maxime y Nick Rees-Roberts (2010), Homo exoticus, Race, Classe et critique queer. Paris, Armand Colin.

Dubet, François (1989), "De la sociología de la identidad a la sociología del sujeto", en Estudios Sociológicos VII: 21, consultado el 15 de octubre de 2013, URL: http://bibliocodex.colmex.mx/ exlibris/aleph/a21_1/apache_media/KF6CHTDP34Y88Y7MHI66P6IY14TVTV.pdf.

Dubois, François-Ronan (2014), Introduction aux Porn Studies. Bruxelles, Les Impressions Nouvelles [versión Kindle].

Gagnon, John H. (1999), "Les usages explicites et implicites de la perspective des scripts dans les recherches sur la sexualité", en Actes de la recherche en sciences sociales, vol. 128, núm. 1, pp. 73-79.

Gagnon, John H. (2004 [1991]), "The explicit and implicit use of scripting perspective in sex research (1991)", en An interpretation of desire. Chicago, The University of Chicago Press, pp. 130-172. 
Giménez Gatto, Fabián (2011), “Parapornografía o la puesta en escena del deseo”, en Ramón del Llano Ibáñez y Lucía Molatore (coord.), Los nuevos círculos del infierno. Querétaro, México, Universidad Autónoma de Querétaro, pp. 69-83.

Giménez Gatto, Fabián (2007), "Pospornografia", en Estudios Visuales. Ensayo, teoría y crítica de la cultura visual y el arte contemporáneo. Murcia, CENDEAC, núm. 5, diciembre 2007, pp. 95-105.

Giménez, Gilberto (2013), "La cultura como identidad y la identidad como cultura”, consultado el 2 de mayo de 2014, URL: http://estudioscultura.wordpress.com/2012/03/13/gilberto-gimenez-la-culturacomo-identidad-y-la-identidad-como-cultura/.

González Villareal, Roberto (2001), Después de la liberación. México, Universidad Pedagógica Nacional.

Gubern, Roman (1989), La imagen pornográfica y otras perversiones ópticas. Madrid, Akal.

Kosofsky Sedgwick, Eve (1998), “Construire des significations queer”, en Didier Eribon (coord.), Les études gay et lesbiennes, Colloque du Centre Georges Pompidou, 23 et 27 juin 1997. Paris, Editions du Centre Pompidou, pp. 109-116.

Laguarda, Rodrigo (2009), Ser gay en la ciudad de México, Lucha de representaciones y apropiaciones de una identidad, 1968-1982. México, CIESAS, Instituto Mora.

Lizarraga Cruchaga, Xabier (1987), "La identidad sexo-genérica: un continuo”, en María Elena Sainz Faulhaber y Xabier Lizarraga Cruchaga (comps.), Estudios de Antropología Biológica. México, UNAM, pp. 383-403.

Núñez Noriega, Guillermo (1999 [1994]), Sexo entre varones. México, UNAM/PUEG.

Núñez Noriega, Guillermo (2005), “Significados y políticas de la “diversidad sexual”: ¿Sanización de la otredad o reivindicaciones de lo polimorfo? Reflexiones teóricas para el activismo”, en Edith Yesenia Peña Sánchez, Francisco Ortiz Pedraza y Lilia Hernández Albarrán, Memorias de la II Semana Cultural de la Diversidad Sexual. México, INAH, pp. 225-228. 
Peña Sánchez, Edith Yesenia y Hernández Albarrán, Lilia (coord.) (2011), ¿Normalización sexual?”, en Iguales pero diferentes: diversidad sexual en contexto, Memorias de la VII Semana Cultural de la Diversidad Sexual, México, INAH, pp. 131-158.

Preciado, Beatriz (2008), Testo Yonqui. Madrid, Espasa Calpe.

Preciado, Beatriz (2010), Pornotopía. Arquitectura y sexualidad en "Playboy" durante la guerra fría. Barcelona, Anagrama.

Touraine, Alain (1994), Qu'est-ce que la démocracie? Paris, Fayard.

Wieviorka, Michel (2008), "Critique du sujet”, en Neuf leçons de sociologie. Paris, Fayard, Pluriel, pp.19-48.

Williams, Linda (1989), Hard Core: Power, Pleasure and the "Frenzy of the Visible". Berkeley, University of California Press.

Yehya, Naief (2004), Pornografía, Sexo mediatizado y pánico moral. México, Plaza y Janés.

Fecha de recepción: 8 de junio de 2014

Fecha de aceptación: 26 de septiembre de 2014 